\title{
Hidroelektrik Santral Gezisinin Ortaokul Öğrencilerinin Kavramsal Anlamalarına Etkisi*
}

\section{The Effect of Hydroelectric Power Plants Trip on Students' Conceptual Understandings}

\author{
Melike YAVUZ TOPALOĞLU**, Fatime BALKAN KIYICI***
}

\begin{abstract}
Öz: Bu araştırma ile sosyobilimsel konuya dayalı okul dışı öğrenme ortamında yürütülen etkinliklerin, 7.sınıf öğrencilerinin kavramsal anlamalarındaki etkisinin belirlenmesi amaçlanmıştır. Tek grup ön testson test deneysel deseninde gerçekleştirilen araştırmaya bir ortaokulda öğrenim görmekte olan toplam 21 yedinci sınıf öğrencisi katılmıştır. Bu kapsamda çalışma grubunda yer alan öğrenciler ile; araştırma kapsamında belirlenen sosyobilimsel konuyla (Hidroelektrik santrali) ilgili okul dışı öğrenme ortamına (ADASU hidroelektrik santrali) ziyaret yapılmıştır. Okul dışı öğrenme ortamında yürütülen ziyaret ve etkinlikler öncesinde ve sonrasında olmak üzere araştırmacı tarafından geliştirilen HES'e yönelik kavramsal anlama testi ön ve son test olarak uygulanmıştır. Kavramsal anlama testinden nicel ve nitel veriler elde edilmiştir. Elde edilen nitel verilerin çözümlenmesinde içerik analizine başvurulurken, nicel verilerin analizinde bağımlı örneklemler t-testi kullanılmıştır. Araştırma sonucunda; sosyobilimsel konulara dayalı okul dışı öğrenme ortamlarında yürütülen etkinliklerin öğrencilerin kavramsal anlamalarını olumlu yönde etkilediği tespit edilmiştir.
\end{abstract}

Anahtar Kelimeler: Okul dışı öğrenme ortamları, hidroelektrik santrali, kavramsal anlama, ortaokul öğrencileri

\begin{abstract}
The aim of this study is to determine the effect of the activities related to socio-scientific issues carried out within out-of-school learning environments on the conceptual understanding of the seventh grade students. A total of twenty one seventh-grade students from a middle school participated in the study which was carried out via experimental design with one group pretest and posttest. Within this context, a visit to the out-of-school learning environment (ADASU Hydroelectric Power Plant) related to the socio-scientific issue (Hydroelectric Power Plant) determined within the scope of the research was made with the students who were selected from the study group. The Conceptual Understanding of HPP Test developed by the researcher was carried out before and after the visit to the out-of-school learning environment. Quantitative and qualitative data were obtained from the conceptual understanding test. While the qualitative data gathered from the tests were analyzed with content analysis method, the paired samples t-test was used for quantitative data analysis. Analysis of the data revealed that activities related to socio-scientific issues carried out in out-of-school learning environments helped students to develop their conceptual learning skills.
\end{abstract}

Keywords: Out-of-school learning environments, hydroelectric power plants, students'opinions, conceptual understanding, middle school students

\section{Giriş}

Yaşam içinde yer alan iklim değişikliği, genetiği değiştirilmiş organizmalar, nükleer santraller, AIDS, klonlama ve silahlanma gibi ve benzeri sosyal sorunlar bilim ve teknolojiyle yakından alakalıdır (Bell ve Lederman, 2003). Bu konular genellikle tartışmalı olan, çeşitli bakış açılarından bakılabilen, basit sonuçları olmayan ve ahlaki ve etik yönlere sahip olan sosyobilimsel konulardır (Kolstø, 2001; Sadler, 2004). Bilim, teknoloji ve fenin sürekli ilerleyişine bağlı olarak bu sosyo-bilimsel konular günlük yaşamımızda etkisini fazlaca göstermektedir

\footnotetext{
*Bu araştırma, Melike Yavuz Topaloğlu'nun Sakarya Üniversitesi Eğitim Bilimleri Enstitüsü'nde Doç. Dr. Fatime Balkan Kıyıcı danışmanlığında tamamlanan doktora tez çalışması kapsamında yapılmıştır.

**Dr., MEB, Kocaeli-Türkiye, e-posta: meykeyavuz@ hotmail.com

***Doç. Dr., Sakarya Üniversitesi, Eğitim Fakültesi, Sakarya-Türkiye, e-posta: fbalkan@ sakarya.edu.tr
} 
(Sadler ve Zeidler, 2004). Bu sebepten; toplumu oluşturan büyükten küçüğe herkesin bu konular dahilin de bilinçlendirilmesi ve bu konularla ilgili incelemeler yapabilecek düzeyde olmasi gerekmektedir (Bilen ve Özel, 2012). Özellikle öğrencilerin gelecekte toplumsal olarak karş1 karşıya kalabilecekleri bu tür problemlerin oluşturacağı durumlara yönelik tedbirleri alabilecek, hem problemleri çözmeye yönelik neler yapılması gerektiği hem de sonucuna karar verebilecek düzeyde olmaları gerekmektedir (Domaç, 2011). Bu bağlamda bugünün çocuklarının gelecekte toplumun çeşitli kesimlerinde yer alan ve söz sahibi fertler olacağı göz önüne alındığında karşılaşacakları sosyo-bilimsel konular hakkındaki bilgi birikimleri ve tutumlarının önemli olduğu vurgulanabilir. Oysa ki hayatın içinde her bireyin bir gün karşı karşıya kalabileceği bu tartışmalı, fikir birliğine varılmayan meselelere ve bu meselelerdeki kavramlara ilişkin bireylerin birçok eksiklik ve yanılgıya sahip olduğu görülmektedir (Dawson, 2007; Demir ve Düzleyen, 2012; Geçit ve Yangın, 2012; Özdemir, 2005; Özden, Akgün, Çinici, Gülmez ve Demirtaş, 2013; Özden, Usak, Prokop, Türkoğlu ve Bahar, 2008; Usak, Erdogan, Prokop ve Özel, 2009). Dolayısıyla toplumda bu konular ile ilgili bir takım eksikliklerin olduğu söylenebilir. Bu sebepten toplumun geleceğinde etkisi olan bu tür tartışmalı konular ile ilgili olarak küçük yaştan itibaren bireylerin bilgi ve farkındalık kazanmalarına yönelik faaliyetlerin yapılması gerektiği ifade edilebilir. Temeli genellikle fene dayananan sosyobilimsel konular ile ilgili bu faaliyetlerin gerçekleştirilmesini sağlayabilecek en uygun yolun fen eğitiminden geçtiği vurgulanabilir.

Okullarda fen eğitimde sosyo-bilimsel konulara yer verilmesiyle; öğrencilerin bu konularda muhakeme yapma ve karar verme becerisi kazanmalarını, bilimsel düşünme alışkanlığı kazanmalarını, konuyla ilgili bilgi edinmelerini, çoklu tartışmalar yürütmelerini sağlamak amaçlanmıştır (Dawson ve Venville, 2010; Milli Eğitim Bakanlığı [MEB], 2013a).

Dolayısıyla sosyo-bilimsel konuların öğretim programında ön görüldügü şekilde doğru ve yeterli şekilde kavratılmaması; bilim ve teknolojinin gelişmesiyle ortaya çıkan sosyo-bilimsel konuların anlaşılmasını, bu konular hakkında kişilerin fikirlerini belirtmelerini, çeşitli tartışmalar yürütmelerini ve konuyla ilgili bir karara varmalarını zorlaştıracağı düşünülmektedir. $\mathrm{Bu}$ bağlamda bu durumun, öğrencilerin fen okuryazarlık düzeylerinin gelişimi üzerinde de negatif yönlü bir etkisi olacağı düşünülmektedir. Oysaki fen eğitiminin en temel amac1 öğrencilerin fen okuryazarı bireyler haline gelmesi (MEB, 2013a), diğer amaçlarından birisi de öğrencilerin fen bilimleri kapsamında yer alan temel kavramları öğrenmeleridir (Kidman, 2010; MEB, 2013a). Bu noktada sosyo-bilimsel konulara dayalı yürütülen fen derslerinin öğrencilerin fen okuryazarı olma, çeşitli becerilerini geliştirme ve kavram öğrenme için oldukça gerekli ve önemli olduğu sonucuna ulaşılabilir. Bu bakımdan fen eğitimde sosyobilimsel konulara yer verilmesinin öğretim programının hedeflerinin gerçekleştirilmesinde destekleyici bir rol oynadığı vurgulanabilir. Dolayısıyla 21. yüzyıl becerilerini taşıyan, tartışmalı ve toplumsal sorunların farkında olan bireyler yetiştirilmesi sağlanabilir.

2005 y1lında kullanılan fen ve teknoloji öğretim programından itibaren güncellenen yeni öğretim programları dahilinde hedeflenen amaçların gerçekleştirilmesinde öğrencilerin yaparak yaşayarak öğrenmeleri, sürece aktif katılım göstermeleri ve yeni bilgilerini ön bilgileriyle ilişkilendirerek yapılandırmalarını sağlayan yaklaşımlar benimsenmiştir (MEB, 2013a). Öğretim programının yönlendirdiği şekilde bireylerin birçok eksikliğe ve yanılgıya sahip olduğu gerçek hayat problemleri olan sosyo-bilimsel konular ile ilgili nitelikli kavram öğretiminin ve bilincin oluşabilmesi için öğrencilere ve ögretmenlere en uygun öğrenme ortamını sunmak oldukça önemlidir. Bu amacı gerçekleştirebilmek için fen bilimleri öğretim programında vurgulanan okul dışı öğrenme ortamları bir araç olarak kullanılabilir.

Okul dışı öğrenme ortamları ile; değişen, geliştirilen ve zenginleştirilen öğrenme ortamı öğrencilerin yaparak yaşayarak ve farklı şekillerde öğrenmesini sağlamaktadır (Ramey-Gassert, 1997). Bunun yanında bireylere sınıf içerisinde sunulması güç olan ilk elden gözlem yapma ve deneyim kazanma firsatı (Emmons, 1997; Rivkin, 2000) ve fen konularıla ilgili kavram ve nesnelerle etkileşimde bulunma ve merak duygusu uyandırma imkanı sunularak tam ve anlamlı öğrenmelerin gerçekleştirilmesi sağlanmaktadır (Ramey-Gassert, 1997). Bu şekilde her birey kendi öğrenmelerini kendisi gerçekleştirebilir. Dolayısıyla anlamlı ve kalıcı öğrenmeler 
gerçekleştirmek, kavramsal anlamalar sağlamak ve fen okuryazarı bireyler yetiştirmek için sınıf içi uygulamalarının yanında okul dışı öğrenme ortamlarına da yer verilmesi gerekmektedir. Benzer şekilde yapılan araştırmalar okul dışı öğrenme ortamlarının fen konularının öğretiminde fen programları kapsamında kullanılması ile öğrencilerin, bu konuları daha iyi ve kolay anlamalarına, kavramalarına (Melber, 2006), kavramları somutlaştırmalarına, anlamlı, etkili, verimli ve kalıcı öğrenmeler edinmelerine katkı sağladığını vurgulamıştır (Braund ve Reiss, 2006; Gerber, Marek ve Cavallo, 2001; Klemmer, Waliczek ve Zajicek, 2005; Randler, Kummer ve Wilhelm, 2012; Salmi 1993; Wellington, 1990). Bu açıdan fen eğitiminde formal eğitim ile gerçekleştirilmesi ve vurgulanması zor olan birçok konu ve kavram kolaylıkla öğrenciye öğretilebilir. Dolayısıyla çelişkili ve tartışmalı olan ve öğrencilerin kavramsallaştırma sürecinde zorlandığı sosyo-bilimsel konuların öğrencilere sınıf ortamından farklı olarak çeşitli imkanlar sunan okul dışı öğrenme ortamlarında ele alınmasının önemli olacağı düşünülmektedir. Çünkü günlük yaşam içerisindeki fikir birliğine varılmayan tartışmalı sosyal sorunlar olan sosyo-bilimsel konulara okul dışı öğrenme ortamlarında yer verilmesiyle; öğrenciler bu konuları kendi doğal ortamında inceleme imkanı elde edebilir. Bu bağlamda bu araştırma öğrencilerin fen bilimleri öğretim programında temel alınan yaklaşımın ön gördüğu şekilde öğrencilerin değişik yollarla anlamlı öğrenmelerine ve konuyla ilgili bilgiyi kendilerine göre yapılandırmalarına firsat vermesi açısından önemlidir. Bu şekilde öğrencilerin ileride karşılaşabilecekleri sosyobilimsel konulara dair yapılabileceklere ilişkin hazırbulunuşluk düzeyleri üzerinde olumlu etkisi olabilir. Ayrıca literatürde genellikle öğretmen adaylarının sosyo-bilimsel konularda kavramsal anlamalarının belirlenmesine ilişkin çalışmaların yer aldığ düşünüldüğünde bu araştırmanın alana katkı sağlayacağı düşünülmektedir. Dolayısıyla bu araştırma kapsamında sosyo-bilimsel konuya dayalı okul dışı öğrenme ortamında yürütülen etkinliklerin 7. sınıf öğrencilerinin kavramsal anlamalarına etkisinin araştırılması amaçlanmıştır.

\section{Yöntem}

\section{Araştırmanın Deseni}

$\mathrm{Bu}$ araştırma kapsamında tek grup ön test-son test deneysel desen kullanılmıştır. Bu desen ile bağımlı değişkene ilişkin ölçümler, uygulama öncesinde öntest, sonrasında son test olarak aynı katılımcılar ve aynı ölçme aracı kullanılarak elde edilerek bağımsı değişkenin bağımlı değişken üzerindeki etkisi araştırılmıştır (Büyüköztürk, Kılıç Çakmak, Akgün, Karadeniz ve Demirel, 2008). Ayrıca buna ek olarak araştırma problemine daha detaylı ve etkili bir yanıt oluşturabilmek için araştırmada kullanılan veri toplama aracından elde edilen veriler nitelleştirilmiştir. Bu bağlamda araştırma kapsamında sosyo-bilimsel konuya dayalı olarak okul dış1 öğrenme ortamında yürütülen etkinliklerin öğrencilerin kavramsal anlamalarına etkisinin belirlemesi amaçlanmıştır. Bu deneysel yöntemde "sosyo-bilimsel konuya dayalı olarak okul dışı öğrenme ortamında yürütülen etkinlik" bağımsız değişken, "öğrencilerin kavramsal anlama testi puanları" ise bağımlı değişkendir. Bağımlı değişkene ilişkin ölçümleri elde etmek için ön ve son test olarak "Sosyobilimsel Konulara Yönelik Kavramsal Anlama Testi" kullanılmıştır. Nicel verilerin elde edildiği bu veri toplama aracından aynı zamanda nitel verilerde elde edilmiştir.

\section{Çalışma Grubu}

Araştırmanın çalışma grubunu 2014-2015 eğitim-öğretim yılında bir ortaokulda öğrenim görmekte olan toplam 21 yedinci sınıf öğrencisi oluşturmaktadır. Araştırma problemine cevap oluşturabilmek amacıyla çalışma grubunda yer alan öğrenciler belirlenirken, amaçlı örnekleme yöntemlerinden ölçüt örnekleme yöntemi kullanılmıştır. Amaçlı örnekleme yöntemlerinden biri olan ölçüt örnekleme ise; araştırılan durumun derinlemesine incelebilmesi için önceden planlanan ölçütleri kapsayan örnek olay türlerinin seçilmesi ve kullanılmasıdır (Ary, Jacobs, Sorensen ve Razavieh 2010; Yıldırım ve Şimşek, 2011). Bu şekilde araştırmacı önceden belirlenmiş olan çeşitli ölçütlere bağlı olarak çalışma grubunda yer alacak öğrencileri seçmiştir. Merriam (2013) amaçlı örnekleme yöntemi çerçevesinde çalışma grubunda öncelikli yer alacak öğrencilerin belirlenmesinin seçim kriterleri kapsamında gerçekleştiğini vurgulamıştır. Bu 
bilgiler 1şı̆̆ında bu araştırma dahilinde; çalışma grubunun seçiminde öğrencilerin 7. sınıf öğrencisi olması, okul dışı öğrenme ortamlarında düzenlenecek etkinliklere katılabiliyor olması ve öğrencilerin sosyobilimsel ve okul dışı öğrenme ortamları ile ilgili temel bilgi ve ilgiye sahip olması ölçütleri referans alınmıştır. Belirlenen bu ölçütlere bağlı olarak çalışma grubunda yer alacak öğrencileri belirlemek için bu ortaokulda bulunan tüm 7. sınıf öğrencilerine bir form uygulanmıştır. Bu form içerisinde okul dışı öğrenme ortamları ve sosyobilimsel konulara dair iki soru, öğrencilerin gönüllülük durumunu belirlemek için ise bir soru bulunmaktadır. $\mathrm{Bu}$ formdan elde edilen veriler doğrultusunda 169 öğrenci arasından sorulara uygun yanıt veren ve gönüllü olan 47 öğrenci seçilmiştir. Daha sonra bu 47 yedinci sınıf öğrencisi arasından ailelerinin okul dışı öğrenme ortamlarında yürütülecek gezilere katılmasına izin verme durumu ve okuldaki öğretmenlerinin öğrenci profili hakkındaki tutumu göz önüne alınarak çalışma grubunda yer alacak 21 kişi belirlenmiştir.

\section{Veri Toplama}

$\mathrm{Bu}$ araştırma kapsamında öğrencilerin HES sosyobilimsel konusu ile ilgili bilgi ve düşüncelerini belirlemek, bu konularla ilgili kavramsal gelişimlerini incelemek ve uygulamanın etkinliğini ortaya koymak amacıyla araştırmacı tarafından geliştirilen "Sosyobilimsel Konulara Yönelik Kavramsal Anlama Testi" kullanılmıştır. Hem nicel hem de nitel verilerin elde edilmesinde kullanılan testte HES ile ilgili 5 soru bulunmaktadır. Öğrencilerin kavramsal anlamalarının ölçülmesinde; ilk aşamada çoktan seçmeli, ikinci aşamadan ise birinci aşamada seçilen seçeneğin gerekçesine ilişskin bulgular ve bilgiler ortaya koyan sorulardan oluşan iki aşamalı testler kullanılmaktadır. (Şahin ve Çepni, 2011; Treagust ve Chandrasegaran, 2007). Bu bağlamda bu araştırma dahilinde kullanılan kavramsal anlama testinde öğrencilerin kavramları anlamalarındaki derinliğin ölçülebilmesi için açık uçlu tanımlayıcı sorular ve iki aşamalı çoktan seçmeli ve neden sorgulayan sorular birlikte kullanılmıştır.

HES'e yönelik kavramsal anlama testi geliştirilirken aşağldaki basamaklar takip edilmiştir:

1. Kavramsal anlama testinde yer alan içeriğin belirlenmesi amacıyla ilk olarak literatürde bulunan sosyobilimsel konular tespit edilmiş ve incelenmiştir. Araştırma kapsamında belirlenen sosyobilimsel konunun okul dış1 öğrenme ortamlarında yürütülmesi söz konusu olduğundan literatürde incelenen sosyobilimsel konular içerisinden araştırmanın amacını gerçekleştirmeye en uygun olan sosyobilimsel konu HES olarak seçilmiştir.

2. Daha sonra Fen Bilimleri ve Fen ve Teknoloji öğretim programında yer alan HES konusu ilgili kazanımlar belirlenmiş ve incelenmiştir. Bunun yanında fen bilimleri veya fen ve teknoloji dersinde okutulan ve MEB'in resmi sitesinde yer alan 7. ve 8. sinif ders kitaplarında (Gündoğdu, 2011; MEB, 2013b; Şahin, 2013; Ünver; 2014); bu konunun yer aldığı bölümlerde geçen kavramlar incelenmiştir.

3. Yapılan incelemelerin ardından kazandırılması planlanan temel kavramlar belirlenmiş ve bu kavramlara yönelik açık uçlu ve iki aşamalı sorular hazırlanmıştır. Sosyobilimsel Konulara İlişkin Kavramsal Anlama Testi Planlaması Tablo 1'de sunulmuştur.

Tablo1

Sosyobilimsel Konulara Yönelik Kavramsal Anlama Testi Planlaması

\begin{tabular}{cllccc}
\hline \multirow{2}{*}{ Ünite } & Hafta & Öğretim & Programında \\
& Yer Alan Kazanımlar & $\begin{array}{c}\text { Sosyo } \\
\text { Bilimsel } \\
\text { Konular }\end{array}$ & Soru & Kavram & $\begin{array}{c}\text { Okul Diş1 } \\
\text { Öğrenme } \\
\text { Ortamı }\end{array}$ \\
\hline
\end{tabular}




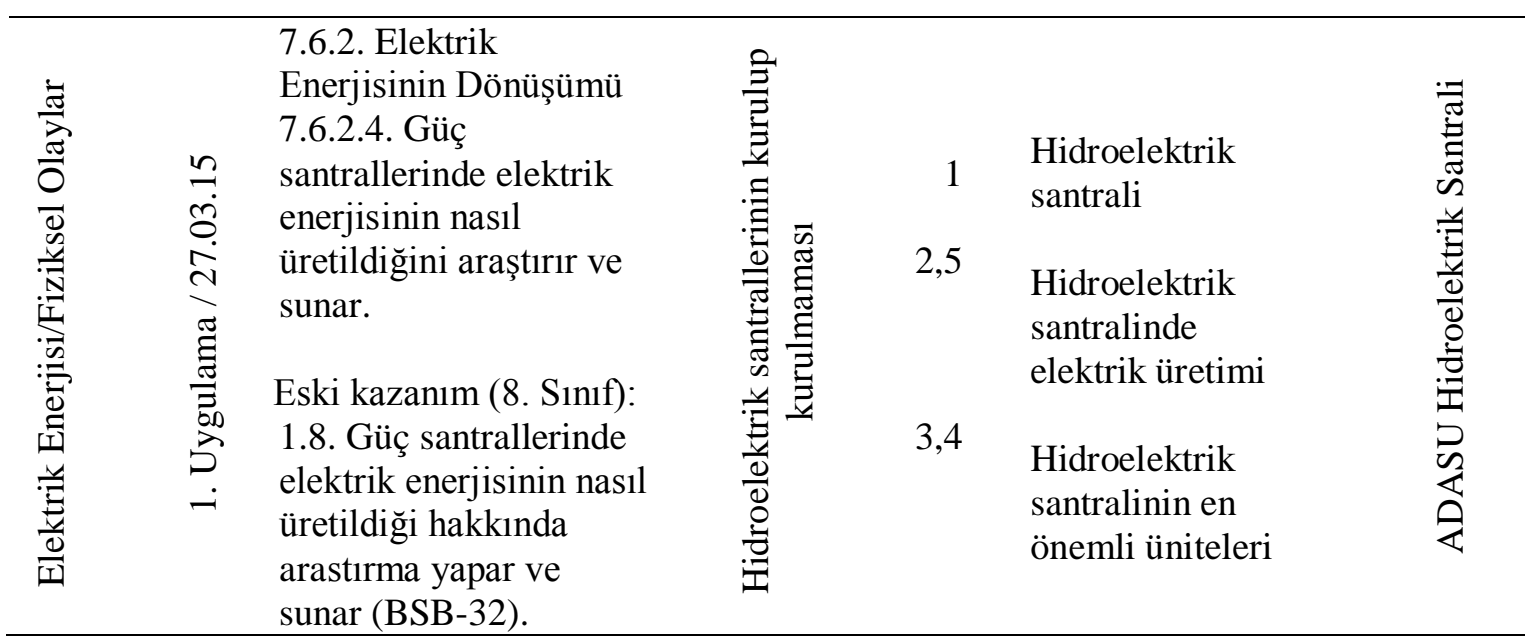

4. Planlamanın ardından oluşturulan taslak formu beş fen eğitimcisi alan uzmanı tarafindan kapsam geçerliliği ve dört fen bilimleri öğretmeni tarafından dilin anlaşılabilirliği ve 7. sınıf seviyesine uygunluğu açısından ayrıntılı bir şekilde incelenerek değerlendirilmiştir. Uzman değerlendirilmesinin yanında, İstanbul Pendik’te bir ortaokulda öğrenim görmekte olan 10 öğrenciye incelemesi için verilmiş, 30 öğrenciye ise uygulanmıştır. $\mathrm{Bu}$ ön deneme uygulaması ile ögrencilerden anlamadıkları noktaları belirtmeleri ve önerilerini yazmaları istenmiştir.

5. Uzman görüşleri ve aynı yaş grubunda yer alan öğrencilerden elde edilen dönütler sonucunda, seviyeye uygun olmayan ve anlaşılmayan sorular formdan çıkartılmış, geriye kalan sorularda eksik ve hatalı görülen noktalar yeniden düzenlenmiş ve ilgi ve motivasyonu artırmak için çeşitli görseller eklenmiştir. Bu şekilde testin kapsam geçerliliğinin artırılması sağlanmıştır.

6. Gerekli düzenlemelerin ardından pilot çalışma için hazırlanan kavramsal anlama testi, 12 tane 7. sınıf ögrencisine uygulanmıştır.

7. Kavramsal anlama testine bağlı yürütülen pilot çalışma sonucunda öğrencilerin karşılaştıkları sıkıntılar belirlenmiş ve gerekli düzeltmeler yapılarak; asıl uygulamada kullanılan kavramsal anlama testinin son hali oluşturulmuştur.

\section{İslem}

Sosyobilimsel konuya dayalı okul dış1 öğrenme ortamında yürütülen etkinliklerin 7.sınıf öğrencilerinin kavramsal anlamalarına etkisinin araştırıldığı bu araştırma kapsamında belirlenen sosyobilimsel konuyla ilgili okul dışı öğrenme ortamına ziyaret yapılmıştır. Bu sebepten; Milli Eğitim Bakanlığı, okul müdürü ve velilerden alınan izinler doğrultusunda çalışma grubunda yer alan 21 yedinci sınıf öğrencisi katılımı ile HES'lerin kurulup kurulmaması konusu 27.03.15 tarihinde ADASU Hidroelektrik Santrali'nde yürütülen etkinliklerle birlikte işlenerek gerçekleştirilmiştir. Araştırmacı tarafindan öğrencilerde merak uyandırmak ve motivasyonu artırmak için; hazırlanan gez-gör-öğren kitapçıkları öğrencilere dağıtılmış ve uygulama boyunca doldurmaları istenmiştir. Uygulama sırasında ise; HES'in ne olduğuna, HES'lerin kurulma amaçlarına, HES'lerde yer alan ünitelere, HES'lerin yararları ve zararlarına ilişkin, ADASU HES tesisi ve orda yapılan çalışmalar hakkında rehber, gözetmen öğretmen ve araştırmacı tarafından daha önceden araştırmacının tasarladığı şekilde bilgiler verilmiş ve gösterilmiştir. Öğrenciler önce santralin yönetim kısmından başlayarak makinaların olduğu yerde bulunan kontrol sistemlerini, orda çalışan kişileri, makinaların çalışma prensibini görerek bilgilenmiştir. Daha sonra merkezin içinde ve dışında olan diğer bölümler gezilmiş ve santralin çalışma ilkelerine dair bilgiler elde edilmiştir. Bu kapsamda okul dış1 öğrenme ortamında yürütülen ziyaret ve etkinlikler öncesinde ve sonrasında olmak üzere HES'e yönelik kavramsal anlama testi ön ve son test olarak uygulanmıştır. 


\section{Verilerin Analizi}

Sosyobilimsel konulara yönelik kavramsal anlama bu testten toplanan verilerin nicelleştirilerek düzenlenmesinde, testte yer alan soru türüne uygun Şahin ve Çepni (2011) ve Ormanc1 ve Şaşmaz-Ören (2010) tarafından geliştirilen puanlama kriterlerine göre hesaplamalar yürütülerek toplam puan hesaplanmıştır. Daha sonra hesaplanan bu puanlar üzerinden istatistiksel analizler gerçekleştirilmiştir. Bu bağlamda; ilk olarak kavramsal anlama testinde yer alan açık uçlu üç soru (birinci, ikinci ve üçüncü soru), Şahin ve Çepni (2011) tarafından geliştirilen iki aşamalı soruların analizinin ikinci basamağında kullanılan puanlama cetveli temel alınarak puanlandırılmıştır. Bu bağlamda Tablo 2'de bu analizde kullanılan kategoriler, kategorilerin puanları ve içeriklerine yer verilmiştir.

Tablo 2

Sosyobilimsel Konulara Yönelik Kavramsal Anlama Testinin İkinci Aşamasının Analizinde Kullanılan Kategoriler, Kategorilerin Puanları ve İçerikleri

\begin{tabular}{|c|c|c|c|}
\hline Kategoriler & $\begin{array}{l}\text { Kategorilerin } \\
\text { Kisaltmalar1 }\end{array}$ & Puanlama & İçerik \\
\hline Doğru Neden & DN & 10 & $\begin{array}{l}\text { Geçerliliği olan nedenin bütün } \\
\text { yönlerini içeren cevaplar }\end{array}$ \\
\hline $\begin{array}{l}\text { Kismen Doğru } \\
\text { Neden }\end{array}$ & $\mathrm{KDN}$ & 8 & $\begin{array}{l}\text { Geçerli gerekçenin bütün yönlerini } \\
\text { içermeyen, bazı yönlerini içeren } \\
\text { cevaplar }\end{array}$ \\
\hline $\begin{array}{l}\text { Kavram Yanılgil1 } \\
\text { Neden }\end{array}$ & KYN & 3 & $\begin{array}{l}\text { Açıklamalarda kavram yanılgısı } \\
\text { içeren ifadeler }\end{array}$ \\
\hline Yanlış Neden & YN & 2 & $\begin{array}{l}\text { Doğru olmayan bilgiler içeren } \\
\text { ifadeler }\end{array}$ \\
\hline İlişkisiz Neden/Boş & $\mathrm{B}$ & 0 & $\begin{array}{l}\text { İlgisiz, soruyla ilgisi anlaşılamayan } \\
\text { cevap verme veya boş bırakma ve } \\
\text { sorunun aynen yazılması durumları }\end{array}$ \\
\hline
\end{tabular}

Açık uçlu soruların puanlandırılmasına ilişkin, öğrencilerin HES'e yönelik olan kavramsal anlama testinin birinci sorusuna verdikleri cevapların Tablo 3'de yer alan puanlama sistemine göre değerlendirilmesine dair bir örnek aşağıda gösterilmiştir.

\section{KDN: "Suyun enerjisi ile üretilen elektrik"(ö6-Ön test)}

Öğrenci cevaplarının kısmen doğru neden kategorisinde değerlendirilmesi için, verilen cevabın bütün yönlerini değil bile en az bir yönünü doğru olarak ifade etmiş olmas1 gerekmektedir. $\mathrm{Bu}$ örnekte hidroelektrik santral tanımı yaparken öğrenci suyun hangi enerjisinden ve ne şekilde yararlanıldığına ilişkin açıklamaya yer verilmediğinden dolayı bu kategoriye dahil edilmiştir.

Kavramsal anlama testinde yer alan dördüncü soru olan çizim sorusundan elde edilen veriler Ormancı ve Şaşmaz-Ören (2010) tarafından çizimleri değerlendirmeye yönelik geliştirilen puanlama cetveli temel alınarak puanlandırılmıştır. Bu bağlamda Tablo 8'de bu analizde kullanılan kategoriler, kategorilerin puanları ve içeriklerine yer verilmiştir.

Tablo 3

Sosyobilimsel Konulara Yönelik Kavramsal Anlama Testinde Yer Alan Çizim Sorusunun Analizinde Kullanılan Kategoriler, Kategorilerin Puanları ve İçerikleri

Kategoriler Kategorilerin Puanlama İçerik

Kisaltmaları

\begin{tabular}{llll}
\hline Tam Anlama & TA & Bilimsel olarak tam doğru olan çizimler
\end{tabular}




\begin{tabular}{|c|c|c|c|}
\hline Kısmen Anlama & KA & 3 & $\begin{array}{l}\text { Bilimsel olarak cevabın bir yönünü } \\
\text { içeren çizimler ya da doğru cevapla } \\
\text { birlikte kavram yanılgısı da içeren } \\
\text { çizimler }\end{array}$ \\
\hline Anlamama & A & 0 & $\begin{array}{l}\text { (a) Tamamen kavram yanılgısı içeren, } \\
\text { (b) bilimsel olarak yanlış olan, (c) ilgisiz } \\
\text { veya anlaşılamayan çizimler, (d) boş } \\
\text { bırakma }\end{array}$ \\
\hline
\end{tabular}

Çizim sorusunun puanlandırılmasına ilişkin, öğrencilerin HES'e yönelik olan kavramsal anlama testinin dördüncü sorusuna verdikleri cevaplarm Tablo 3'te yer alan puanlama sistemine göre değerlendirilmesine dair bir örnek aşağıda gösterilmiştir.

A:

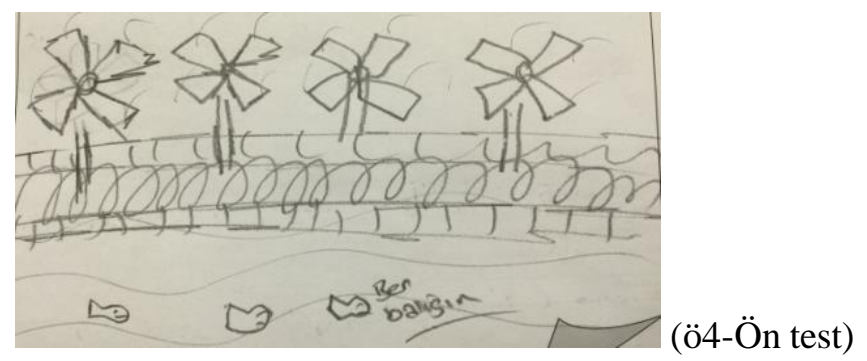

Öğrenci cevaplarının anlamama kategorisinde değerlendirilmesi için, tamamen kavram yanılgısı içermesi, bilimsel olarak yanlış, soruyla ilgisiz ve anlaşılmayan çizimler olması veya boş bırakılması gerekmektedir. Bu örnekte öğrenci verilen kavramlarının hiç birini kullanmamış ve bilimsel olarak yanlış olan bir çizim yaptığından dolayı bu çizime bu kategoride yer verilmiştir.

Kavramsal anlama testinde yer alan beşinci sorudan elde edilen veriler Şahin ve Çepni (2011) tarafından geliştirilen iki aşamadan oluşan soruların analizinde kullanılan puanlama cetvelinde yer alan 11 kategoriye bağlı olarak puanlandırılmıştır. Bu bağlamda iki aşamadan oluşan sorunun ilk aşaması Doğru Seçenek (DS), Yanlış Seçenek (YS) ve Boş (B) olmak üzere üç kategori altında analiz edilmiştir. Soruların ikinci aşamasında yer alan "Neden?" sorusuna verilen cevapların analizi sırasında; Doğru Neden (DN), Kısmen Doğru Neden (KDN), Kavram Yanılgılı Neden (KYN), Yanlış Neden (YN), İlişkisiz Neden/ Boş (B) kategoriler oluşturulmuştur. Öğrencilerin yanlış seceneği işaretlemesinin hiç birşey bilmediği şeklinde yorumlanmaması için YS'ye 1 puan, B'ye 0 puan verilerek kategorize edilmiştir. DS ve YS işaretleyen öğrenciler arasında belirgin bir fark olması için de DS 5 puan olarak belirlenmiştir (Şahin ve Çepni, 2011). Sosyobilimsel konulara ilişkin kavramsal anlama testlerinde yer alan iki aşamalı soruların analizde kullanılan kategoriler, kategorilerin puanları ve içerikleri Tablo 4'te sunulmuştur.

Tablo 4

Sosyobilimsel Konulara Yönelik Kavramsal Anlama Testinin Analizinde Kullanılan Kategoriler ve Puanlar

\begin{tabular}{llr}
\hline \multicolumn{1}{c}{ Kategoriler } & Kategorilerin & Puanlama \\
& Kısaltmaları & \\
\hline Doğru Seçenek-Doğru Neden & DS-DN & 15 \\
Doğru Seçenek-K1smen Doğru Neden & DS-KDN & 13 \\
Yanlış Seçenek- Doğru Neden & YS-DN & 11 \\
Yanlş Seçenek- Kısmen Doğru Neden & YS-KDN & 9 \\
Doğru Seçenek- Kavram Yanılgılı Neden & DS-KYN & 8 \\
Doğru Seçenek- Yanlış Neden & DS-YN & 7 \\
Doğru Seçenek-Boş & DS-B & 5 \\
\hline
\end{tabular}




\begin{tabular}{lll}
\hline Yanlış Seçenek-Kavram Yanılgılı Neden & YS-KYN & 4 \\
Yanlış Seçenek-Yanlış Neden & YS-YN & 3 \\
Yanlış Seçenek- İlişkisiz/Boş & YS-B & 1 \\
Boş-İlişkisiz/Boş & B-B & 0 \\
\hline
\end{tabular}

İki aşamalı soruların puanlandırılmasına ilişkin, öğrencilerin HES'e yönelik olan kavramsal anlama testinin beşinci sorusuna verdikleri cevapların Tablo 6' da yer alan puanlama sistemine göre değerlendirilmesine dair bir örnek aşağıda gösterilmiştir.

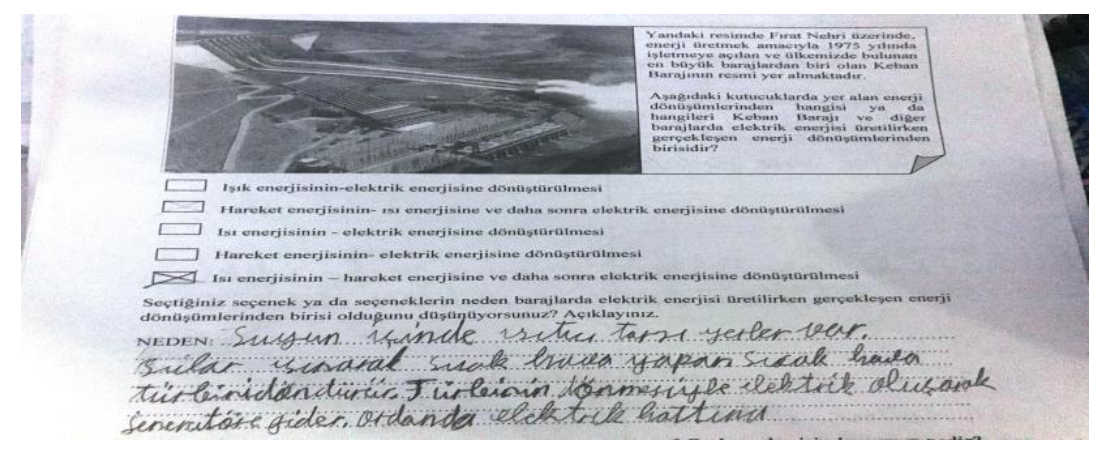

YS-YN: "Çünkü arkadaşı bunu gönül rahatlı̆̆ıyla yapar. Aslında bunun aynısını akrabalarıda yapar. Ama bence arkadaşları daha uygun olur." (ö8-Ön test)

Öğrenci cevaplarının yanlış seçenek-yanlış neden kategorisinde değerlendirilmesi için, ilk olarak verilen şıklar içerisinde "hareket enerjisinin-elektrik enerjisine dönüştürülmesi”" şık1 dışında farklı bir şık işaretlemiş olması gerekmektedir. Bunun yanında doğru olmayan bilgiler içeren cevap vermiş olması gerekmektedir. Yukarıdaki örnekte öğrenci HES'lerde meydana gelen enerji dönüşümünün suyun ısınması ile ilgili olduğunu belirtmesi nedeniyle bu örnek bu kategoride yer almıştır.

Kavramsal anlama testinde yer alan soruların puanlama kriterlerine göre hesaplanması sonucunda HES'e yönelik olan kavramsal anlama testtinden alınacak en yüksek puan 70 olacak şekilde hesaplanmıştır. Tablo 5'da Sosyobilimsel konulara ilişkin kavramsal anlama testlerinin her birine ait sorular ve bu sorulardan alınacak en yüksek puanlar ayrıntılı olarak yer almaktadır.

Tablo 5

Sosyobilimsel Konulara Yönelik Kavramsal Anlama Testlerinin Her Birine Ait Sorular ve Bu Sorulardan Alınacak En Yüksek Puanlar

\begin{tabular}{ccccccc}
\hline & 1.soru & 2 soru & 3.soru & 4.soru & 5.soru & Toplam \\
\hline \multirow{3}{*}{ HES } & 10 & 10 & 30 & 5 & 15 & \\
& Açık & Açık & Aç1k & Çizim & İki & 70 \\
& Uçlu & Uçlu & Uçlu & & Aşamalı & \\
\hline
\end{tabular}

Sosyobilimsel Konulara Yönelik Kavramsal Anlama Testinden elde edilen puanların genel dağılımlarının ve normal dağılım gösterip göstermediğinin belirlenmesi için ilk olarak betimsel istatistik tekniklerinden faydalanılmıştır. Ayrıca bu testen elde edilen puanlara bağlı olarak Shapiro-Wilk testi sonuçları saptanmıştır. Elde edilen bu sonuçlar doğrultusunda veri analizinde hangi analizin kulanılacağına karar verilmiştir. Bu doğrultuda sosyobilimsel konuya dayalı okul dış1 öğrenme ortamında yürütülen etkinliklerin 7.sınıf öğrencilerinin kavramsal anlamalarına etkisini sorgulamak amacıyla bağımlı örneklemler t-testi (İlişkili örneklemler ttesti) kullanılmıştır.

Kavramsal anlama testinden elde edilen nitel verilerin analizinde içerik analizine başvurulmuştur. Tümevarımcı yaklaşımı temel alan içerik analizi ile veriler ilk olarak verilerin kodlanması, benzer kodların temalar altında toplanması, bu kod ve temaların düzenlemesi ve 
tanımlanması ve son olarak elde edilen bulguların yorumlanması şeklinde ilerlemektedir (Charles ve Mertler, 2002; Yıldırım ve Şimşek, 2011).

İçerik analizi sonucunda veri analizinin güvenirliğini sağlamak kavramsal anlama testine ait veriler fen eğitiminde yüksek lisans yapmış ve deneyimli bir fen bilimleri öğretmeni olan bir araştırmacıya sunulmuştur. Bu bağlamda bu araştırmacının öğrencilerden elde edilen yazılı metinleri okuyarak kod ve temaları incelemeleri ve değerlendirmeleri istenmiştir. $\mathrm{Bu}$ doğrultuda farklı araştırmacının, araştırmacıdan bağımsız yaptığı incelemelere dayanarak kodların tutarlılığını belirlemek amacıyla görüş birliği ve görüş ayrılığını kapsayan Miles ve Huberman'ın (1994:64) belirttiği formülle hesaplamalar yapılmıştır. Bu formül kapsamında araştırmacı ve ikinci araştırmacının uyumlu olduğu kodlar görüş birliğine, farklı olan kodlar, ikinci araştırmacı tarafindan eklenen ya da çıkartılan kodlar görüş ayrılığı kısmına bir puan olarak eklenerek hesaplamalar yapılmıştır. Kavramsal anlama testinden elde edilen verilerin analizlerinin değerlendirme yüzdesi \%80 olarak bulunmuştur. Yıldırım ve Şimşek'e (2011) göre; hesaplamalar sonucunda kodlamalarda benzerlik ve farklılıklardan oluşan iki araştırmacı arasındaki değerlendirme yüzdesinin en az \%70 düzeyinde olması analiz sürecinin güvenilir olduğunu göstermektedir. Dolayısıyla bu araştırmadaki nitel veri analiz süreçlerinin güvenilir olduğu ifade edilebilir.

\section{Bulgular}

HES konusuna yönelik hidroelektrik santralinde yürütülen etkinlikler ile ilgili kavramsal anlama düzeyine etkisine ilişkin bulgular

Öğrencilerin HES'e yönelik kavramsal anlama ön ve son test puan ortalamaları Bağımlı Örneklemler T-Testi kullanılarak karşılaştırılmış ve gerçekleştirilen analiz sonuçları Tablo 6' da sunulmuştur.

Tablo 6

Öğrencilerin HES'e Yönelik Kavramsal Anlama Ön ve Son Test Puan Ortalamalarının T-Testi Sonuçları

\begin{tabular}{lllrrrr}
\hline \multicolumn{1}{c}{ Ölçüm } & $\mathrm{N}$ & $\mathrm{X}$ & $\mathrm{S}$ & $\mathrm{sd}$ & $\mathrm{t}$ & $\mathrm{P}$ \\
\hline Ön test & 21 & 36.095 & 10.103 & 20 & -10.650 & .000 \\
Son test & 21 & 58.285 & 6.301 & & & \\
\hline
\end{tabular}

Tablo 6 incelendiğinde HES'e yönelik kavramsal anlama testi ile elde edilen, öğrencilere ait son test puanlarının ön test puanlarından anlamlı bir şekilde farklılaştığ görülmektedir [t20 $=-10.650, \mathrm{p}<0.05]$. Bulunan bu fark, son test puanları lehinedir. Çalışma grubunda yer alan öğrencilerin sosyobilimsel konuya dayalı okul dişı öğrenme ortamında yürütülen etkinlikler öncesi kavramsal anlama ön test puan ortalamasının (36.095), uygulama sonrasında son test puan ortalamasından (58.285) daha yüksek olduğu görülmektedir. Bu doğrultuda HES konusuna yönelik hidroelektrik santralinde yürütülen etkinlikler çalışma grubunda yer alan öğrencilerin; HES konusu ile ilgili kavramsal anlama düzeylerinde anlamlı ve olumlu yönde bir etki yaratmıştır. Cohen (1988)'e göre etki büyüklügünün 0.138 'den büyük olması ilgilenilen değişkenin büyük etkiye sahip olduğunun göstergesidir. Bu analiz için etki büyüklüğü hesaplandığında, etki büyüklüğünün oldukça yüksek olduğu $\left(\eta^{2}=0.850\right)$, HES konusuna yönelik hidroelektrik santralinde yürütülen etkinliklerin öğrenme üzerinde büyük etkiye sahip olduğu saptanmıştır.

HES konusuna yönelik hidroelektrik santralinde yürütülen etkinliklerde yer alan kavramlara ilişkin bulgular

HES'e yönelik olan kavramsal anlama testinde yer alan birinci soru ile öğrencilerin hidroelektrik santrali tanımına ilişkin bilgileri belirlenmiştir. Cevapların analizi sonucunda elde edilen kod ve temalar ile bu kodların sıklık frekansı ve yüzde oranlarına Tablo 7'de yer verilmiştir. 
Tablo 7

Hidroelektrik Santrali Tanımına İlişkin Öğrencilerin Cevapları

\begin{tabular}{|c|c|c|c|c|c|c|c|c|c|}
\hline Tema & Kodlar & Ön test & $\begin{array}{c}\text { Siklık } \\
\text { frekans1 }\end{array}$ & Yüzde & Yüzde & Son test & $\begin{array}{c}\text { Siklık } \\
\text { frekans1 }\end{array}$ & Yüzde & Yüzde \\
\hline \multirow{5}{*}{ 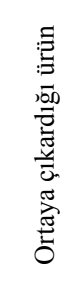 } & Enerji üretme & ö1,ö4,ö13,ö19 & 4 & 7.41 & & & & & \\
\hline & Elektrik & ӧ2,ö4,ö5,ö6,ö7, & & 18.52 & & ӧ2,ö5,ö6,ö7, & & 12.73 & \\
\hline & üretme & $\begin{array}{r}\text { ö8,ö10,ö12,ö16, } \\
\text { ö17 }\end{array}$ & 10 & & & ö8,ö9,ö12 & 7 & & \\
\hline & $\begin{array}{l}\text { Elektrik } \\
\text { enerjisi }\end{array}$ & $\begin{array}{r}\text { ö1,ö9,ö14,ö15, } \\
\text { ö18,ö19,ö20, }\end{array}$ & & 14.81 & 40.74 & $\begin{array}{c}\text { ö1,ö3,ö4,̈̈5, } \\
\text { ö10,ö11,ö13, }\end{array}$ & & 27.27 & 40.00 \\
\hline & üretme & ӧ21 & 8 & & & $\begin{array}{r}\text { ö14,ö15,ö16, } \\
\text { ö17,ö18,ö19, } \\
\text { ö20,ö21 }\end{array}$ & 15 & & \\
\hline \multirow{3}{*}{ 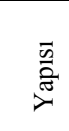 } & Baraj & ö2,ö8,ö11,ö19, & 5 & 9.26 & \multirow{3}{*}{12.96} & ӧ2,ö8 & 2 & 3.64 & \multirow{3}{*}{3.64} \\
\hline & Set & 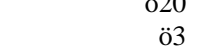 & 1 & 1.85 & & & & & \\
\hline & Köprü & ö4 & 1 & 1.85 & & & & & \\
\hline \multirow{8}{*}{ 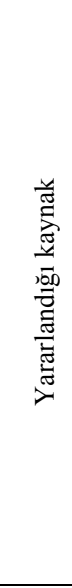 } & $\begin{array}{l}\text { Suyun } \\
\text { enerjisi ile }\end{array}$ & ö6 & 1 & 1.85 & \multirow{8}{*}{46.28} & ӧ9,ö13,ö20 & 3 & 5.45 & \multirow{8}{*}{56.36} \\
\hline & $\begin{array}{l}\text { Suyun } \\
\text { hizından }\end{array}$ & ö7,ö19 & 2 & 3.70 & & ö1,ö14 & 2 & 3.64 & \\
\hline & $\begin{array}{l}\text { Suyun } \\
\text { toplanmasi ile }\end{array}$ & ö8,ö13,ö21 & 3 & 5.55 & & ö15,ö16,ö18 & 3 & 5.45 & \\
\hline & $\begin{array}{l}\text { Enerji } \\
\text { dönüşümü ile }\end{array}$ & ö9,ö15,ö18,ö20 & 4 & 7.41 & & $\begin{array}{l}\text { ö3,̈̈7,ö9,ö10, } \\
\text { ö13,ö14,ö15, } \\
\text { ̈̈16,̈18,021 }\end{array}$ & \multirow[t]{2}{*}{10} & 18.18 & \\
\hline & $\begin{array}{l}\text { Suyun } \\
\text { hareket } \\
\text { enerjisi ile }\end{array}$ & ö9 & 1 & 1.85 & & 010,010,021 & & & \\
\hline & $\begin{array}{l}\text { Makineler } \\
\text { yardımıyla }\end{array}$ & ö15,ö18 & 2 & 3.70 & & ӧ2 & \multirow[t]{2}{*}{1} & 1.82 & \\
\hline & Su yardımıyla & ö2,ö3,ö7,ö8,ö10 & & 22.22 & & ö1,ö2,ö3,ö4, & & 21.82 & \\
\hline & & 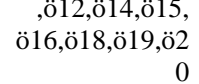 & 12 & & & $\begin{array}{r}\text { Ö5,ö6,ö7,ö10, } \\
\text { ö11,ö12,ö14, } \\
\ddot{0} 19\end{array}$ & 12 & & \\
\hline & Toplam & Tüm öğrenciler & 54 & 100 & 100 & $\begin{array}{c}\text { Tüm } \\
\text { öğrenciler }\end{array}$ & 55 & 100 & 100 \\
\hline
\end{tabular}

Tablo 7'de hidroelektrik santrali tanımına ilişkin öğrencilerin kavramsal anlama ön ve son testlerine verdiği cevaplar "ortaya çıkardığı ürün, yapısı ve yararlandığı kaynak" olmak üzere üç tema altında toplanmıştır. Hidroelektrik santrali tanımına ilişkin öğrencilerin kavramsal anlama ön testine verdiği cevaplar incelendiğinde; \%46.28'inin hidroelektrik santralinin "yararlandığı kaynağa" dayalı ifadelere yer verdiği görülmektedir. Aynı soruya ilişkin öğrencilerin kavramsal anlama son testine verdiği cevaplar incelendiğinde ise; \%56.36'sının hidroelektrik santralinin "yararlandığı kaynağa" dayalı ifadelere vurgu yaptığı belirlenmiştir. Ön ve son testlerden elde edilen bu bulgular doğrultusunda; öğrencilerin hidroelektrik santrali tanımı yaparken yararlandığı kaynağa dayalı açıklamalara yer vermiş olduğu tespit edilmiştir.

Öğrencilerin hidroelektrik santralinin tanımına ilişkin ön testte verdikleri cevaplardan alıntılar aşağıdaki şekilde verilmiştir:

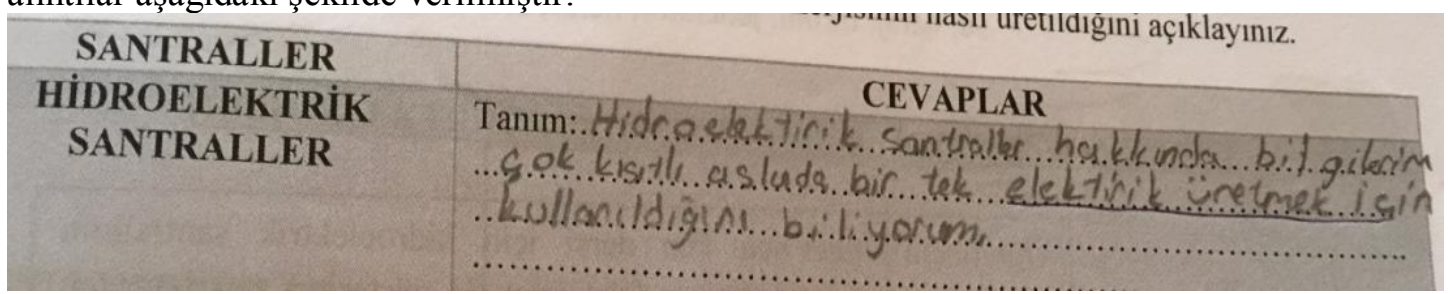

ö5 kodlu öğrencinin yanıtı 


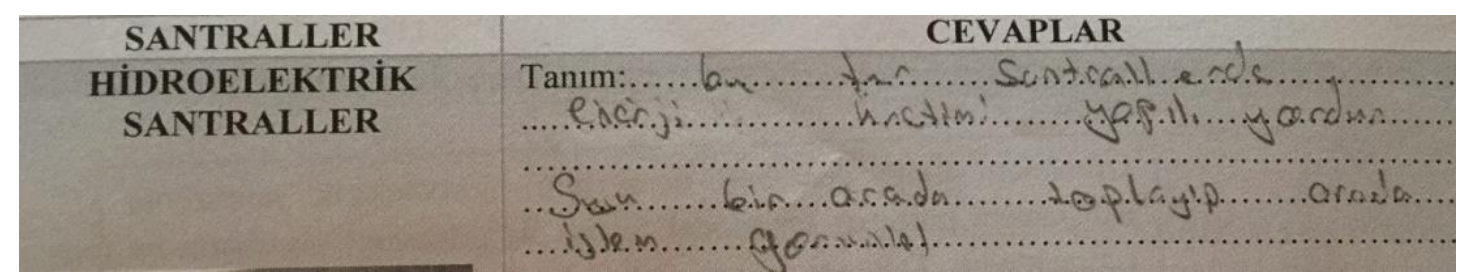

ö13 kodlu öğrencinin yanıt1

Öğrencilerin hidroelektrik santralinin tanımına ilişkin son testte verdikleri cevaplardan alıntılar aşağıdaki şekilde verilmiştir:

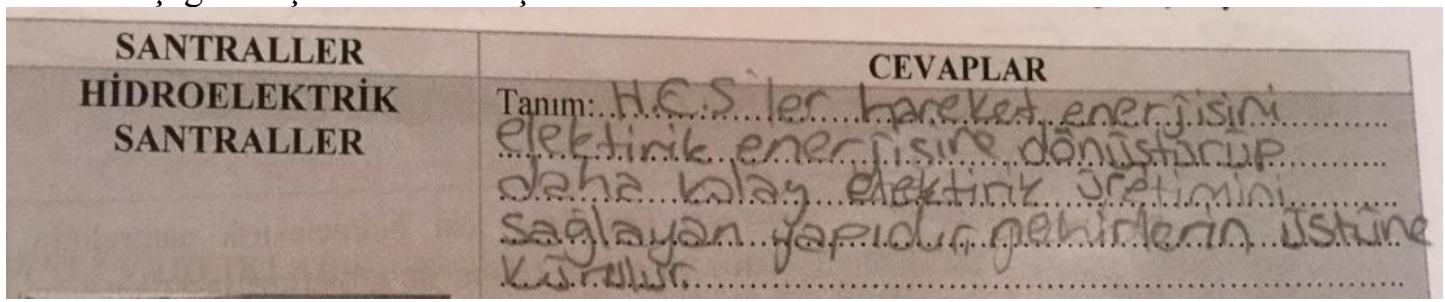

ö7 kodlu öğrencinin yanıtı

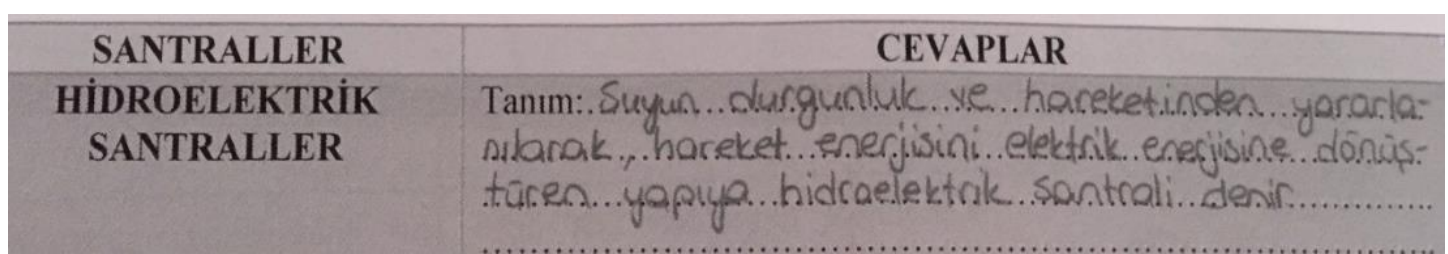

ö14 kodlu öğrencinin yanıtı

HES'e yönelik olan kavramsal anlama testinde yer alan ikinci soru ile öğrencilerin hidroelektrik santralinde elektrik enerjisinin nasıl üretildiğine ilişkin bilgileri belirlenmiştir. Cevapların analizi sonucunda elde edilen kod ve temalar ile bu kodların sıklık frekansı ve yüzde oranlarına Tablo 8'de yer verilmiştir.

Tablo 8

Hidroelektrik Santralinde Elektrik Enerjisi Üretimine İlişkin Öğrencilerin Cevapları

\begin{tabular}{|c|c|c|c|c|c|c|c|c|c|}
\hline Tema & Kodlar & Ön test & $\begin{array}{c}\text { S1kl1k } \\
\text { frekans1 }\end{array}$ & Yüzde & Yüzde & Son test & $\begin{array}{c}\text { Sıklık } \\
\text { frekansı }\end{array}$ & Yüzde & Yüzde \\
\hline \multirow{8}{*}{ 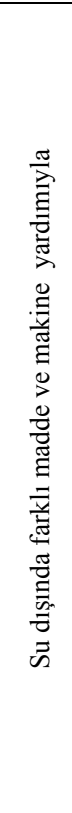 } & $\begin{array}{l}\text { Yeraltında } \\
\text { bulunan } \\
\text { kablolarla }\end{array}$ & ö1,ö4 & 2 & 9.52 & & & & & \multirow{8}{*}{75.63} \\
\hline & $\begin{array}{l}\text { Sette bulunan } \\
\text { yapilar ile }\end{array}$ & ö3 & 1 & 4.76 & & & & & \\
\hline & $\begin{array}{l}\text { Türbinin } \\
\text { dönmesi ile }\end{array}$ & & & & & $\begin{array}{r}\text { ö1,ö2,ö3,ö4,ö5 } \\
\text { „ö6,ö7,ö8,ö9, } \\
\text { ö10,ö11,ö12, } \\
\text { ö13,ö14,ö15, } \\
\text { ö16,ö17,ö18, } \\
\text { ö19,ö20,ö21 }\end{array}$ & 21 & 26.92 & \\
\hline & Jeneratörün & & & & & ö1,ö2,ö3,ö4,ö6 & 19 & 24.36 & \\
\hline & çalışmasıyla & & & & 23.80 & $\begin{array}{r}\text {,ö7,ö8,ö9,ö10, } \\
\text { ö11,ö12,ö13, } \\
\text { o114,ö15,ö16, } \\
\text { ö18,ö19,ö20, } \\
\text { ö21 }\end{array}$ & & & \\
\hline & $\begin{array}{l}\text { Milin jeneratörü } \\
\text { çalıştırması ile }\end{array}$ & & & & & $\begin{array}{r}\text { ö1,ö2,ö3,,̈6,ö7 } \\
\text {,ö8,ö9,ö10,ö11 } \\
\text {,ö12,ö14,ö15, } \\
\text { ö16,ö18,ö19, } \\
\ddot{o ̈ 20, o ̈ 21 ~}\end{array}$ & 17 & 21.79 & \\
\hline & $\begin{array}{l}\text { Şaftın } \\
\text { dönmesiyle }\end{array}$ & & & & & ö5,ö17 & 2 & 2.56 & \\
\hline & Barajdaki & ö10 & 1 & 4.76 & & & & & \\
\hline
\end{tabular}




\begin{tabular}{|c|c|c|c|c|c|c|c|c|c|}
\hline & $\begin{array}{l}\text { pervane ile } \\
\text { Elektrik } \\
\text { tellerinden }\end{array}$ & ö5 & 1 & 4.76 & & & & & \\
\hline \multirow{8}{*}{ 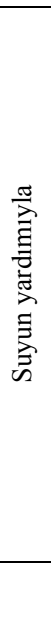 } & Barajdaki su ile & ӧ2,ö6 & 2 & 9.52 & & $\begin{array}{r}\text { ö2,ö3,ö6,ö7,ö8 } \\
\text {,ö11,ö12,ö15 } \\
\text { „ö18,ö19,ö20, } \\
\text { ö21 }\end{array}$ & 12 & 15.38 & \multirow{7}{*}{23.45} \\
\hline & Suyun akmass ile & $\begin{array}{c}\text { ö7,ö19, } \\
\text { ö14,ö20 }\end{array}$ & 4 & 19.05 & & & & & \\
\hline & $\begin{array}{l}\text { Suyun isinmasi } \\
\text { ile }\end{array}$ & ö8 & 1 & 4.76 & & & & & \\
\hline & $\begin{array}{l}\text { Suyun baraja } \\
\text { çarpmasiyla }\end{array}$ & ö9,ö11 & 2 & 9.52 & 76.17 & & & & \\
\hline & Su ile & ö12,ö13,ö17 & 3 & 14.28 & & $\begin{array}{l}\text { ö1,ö4,ö5,ö99, } \\
\text { ö10,ö14,ö16 }\end{array}$ & 7 & 8.07 & \\
\hline & Suyun gücü ile & ö16 & 1 & 4.76 & & & & & \\
\hline & $\begin{array}{l}\text { Suyun } \\
\text { makinelerdeki } \\
\text { işlemlerden } \\
\text { geçmesi ile }\end{array}$ & ö15,ö18,ö21 & 3 & 14.28 & & & & & \\
\hline & Toplam & $\begin{array}{c}\text { Tüm } \\
\text { öğrenciler }\end{array}$ & 21 & 100 & 100 & Tüm öğrenciler & 78 & 100 & 100 \\
\hline
\end{tabular}

Tablo 8'de hidroelektrik santralinde elektrik enerjisi üretimine ilişkin öğrencilerin kavramsal anlama ön ve son testlerine verdiği cevaplar "su dışında farklı madde ve makine yardımıyla ve suyun yardımıyla" olmak üzere iki tema altında toplanmıştır. Hidroelektrik santralinde elektrik enerjisi üretimine ilişkin öğrencilerin kavramsal anlama ön testine verdiği cevaplar incelendiğinde; \%76.17'sinin "suyun yardımıyla" elektrik enerjisi üretildiğine dair ifadelere yer verdiği görülmektedir. Aynı soruya ilişkin öğrencilerin kavramsal anlama son testine verdiği cevaplar incelendiğinde ise; \%75.63'ünün "su dışında farklı madde ve makine yardımıyla" elektrik enerjisi üretildiğine dair ifadelere vurgu yaptı̆̆ı belirlenmiştir. Ön testlerden elde edilen bu bulgular doğrultusunda; öğrencilerin hidroelektrik santralinde elektrik enerjisi üretiminde suyun yardımının, son testlerden elde edilen bu bulgular doğrultusunda ise; su dışında farklı madde ve makine yardımının oynadığ 1 rollerle ilgili açıklamalara yer verdiği görülmektedir.

Öğrencilerin hidroelektrik santralinde elektrik enerjisi üretimine ilişkin ön testte verdikleri cevaplardan alıntılar aşağıdaki şekilde verilmiştir:

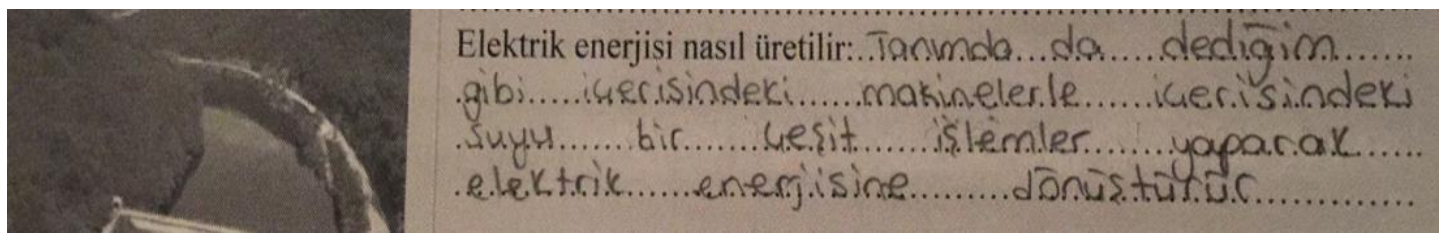

ö15 kodlu öğrencinin yanıtı

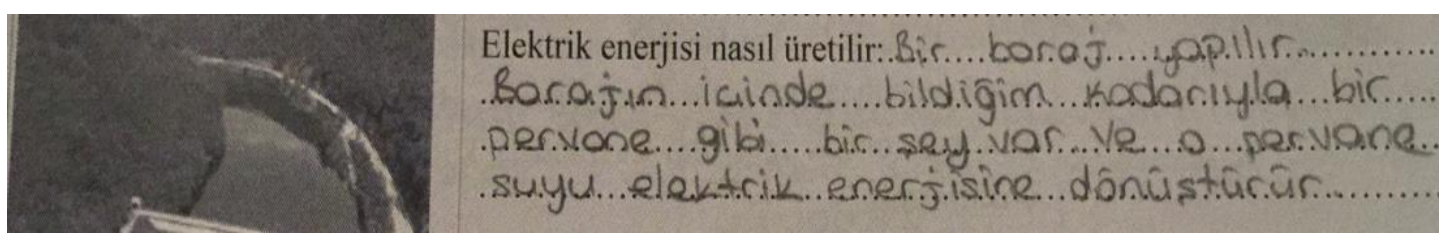

ö10 kodlu öğrencinin yanıt1

Öğrencilerin hidroelektrik santralinde elektrik enerjisi üretimine ilişkin son testte verdikleri cevaplardan alıntılar aşağıdaki şekilde verilmiştir: 


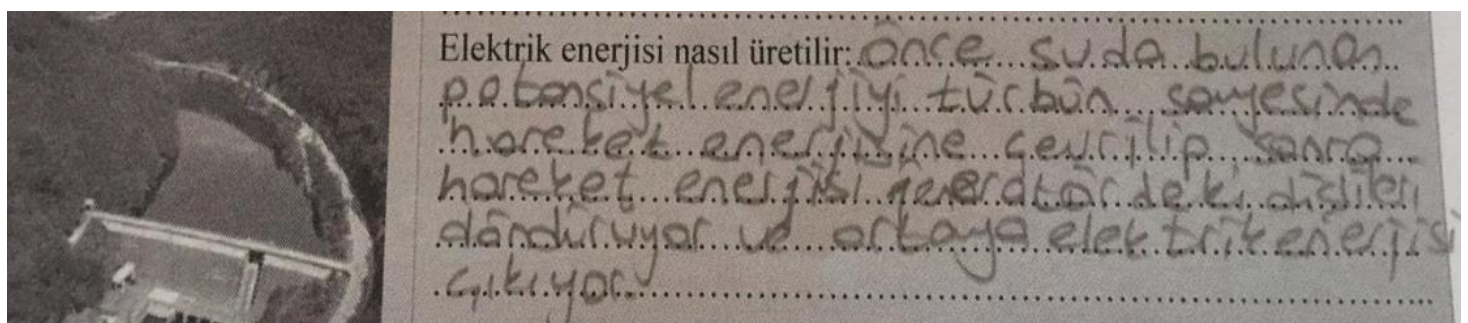

ö9 kodlu öğrencinin yanıtı

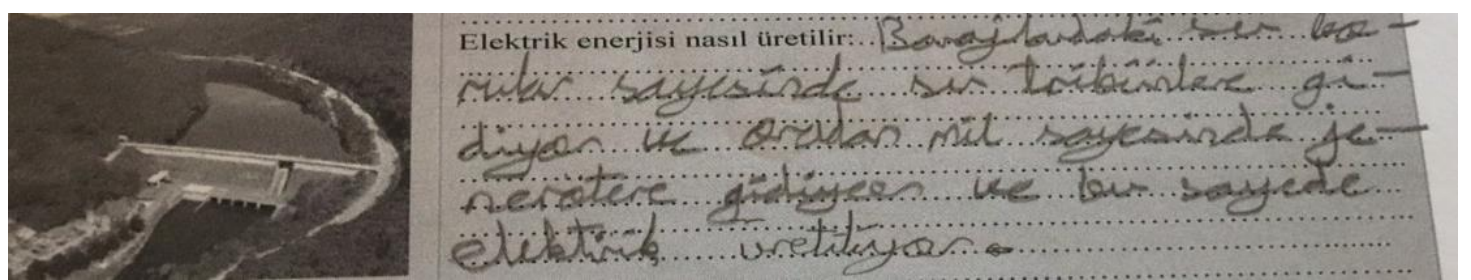

ö2 kodlu öğrencinin yanıtı

HES'e yönelik olan kavramsal anlama testinde yer alan dördüncü soru ile öğrencilerin hidroelektrik santrali ile ilgili çizimlerine ilişkin bilgileri belirlenmiştir. Çizimlerin analizi sonucunda elde edilen kod ve temalar ile bu kodların sıklık frekansı ve yüzde oranlarına Tablo 9'da yer verilmiştir.

Tablo 9

Hidroelektrik Santraline İlișkin Öğrencilerin Çizimleri

\begin{tabular}{|c|c|c|c|c|c|c|c|}
\hline Tema & Kodlar & Ön test & $\begin{array}{l}\text { Siklik } \\
\text { frekansı }\end{array}$ & Yüzde & Son test & $\begin{array}{l}\text { Siklık } \\
\text { frekansı }\end{array}$ & Yüzde \\
\hline \multirow{10}{*}{ 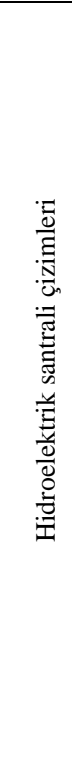 } & $\begin{array}{l}\text { Su, } \\
\text { türbin,jeneratör,elektri } \\
\mathrm{k} \text { hattı }\end{array}$ & & & & ö1 & 1 & 4.76 \\
\hline & $\begin{array}{l}\text { Su, baraj, } \\
\text { türbin,jeneratör,elektri } \\
\text { k hattı }\end{array}$ & & & & ӧ2,ö7 & 2 & 9.52 \\
\hline & $\begin{array}{l}\text { Su, baraj, } \\
\text { türbin,jeneratör }\end{array}$ & ӧ7,ö9 & 2 & 9.52 & & & \\
\hline & Su,baraj & $\begin{array}{r}\text { ö10,ö11,ö12,ö13, } \\
\text { ô15,ö16,ö17,ö18, } \\
\text { ö19,ö20,ö21 }\end{array}$ & 11 & 52.38 & ö13 & 1 & 4.76 \\
\hline & $\begin{array}{l}\text { Su, } \\
\text { baraj,jeneratör,nehir }\end{array}$ & ӧ2 & 1 & 4.76 & & & \\
\hline & $\begin{array}{l}\text { Su, } \\
\text { baraj,jeneratör,nehir,el } \\
\text { ektrik hatt1 }\end{array}$ & ö8,ö14 & 2 & 9.52 & & & \\
\hline & $\begin{array}{l}\text { Su, baraj, } \\
\text { nehir,elektrik hattı, }\end{array}$ & ö5 & 1 & 4.76 & & & \\
\hline & Hepsi & ӧ3,ö6 & 2 & 9.52 & $\begin{array}{r}\text { ö3,ö4,ö5,ö6,ö8,ö9, } \\
\text { ö10,ö11,ö12,ö14, } \\
\text { ö15,ö16,ö17,ö18, } \\
\text { ö19,ö20,ö21 }\end{array}$ & 17 & 80.95 \\
\hline & Konuyla alakasız & ö1,ö4 & 2 & 9.52 & & & \\
\hline & Toplam & Tüm öğrenciler & 21 & 100 & Tüm öğrenciler & 21 & 100 \\
\hline
\end{tabular}

Tablo 9'da hidroelektrik santraline ilişkin öğrencilerin çizimleri incelendiğinde; \%52.38'inin "su, baraj" șekillerine dayalı çizimler yaptığı belirlenmiștir. Aynı soruya ilișkin öğrencilerin kavramsal anlama son testinde yer alan çizimleri incelendiğinde ise; \%80.95'inin "hepsini (su, baraj, türbin, jeneratör, elektrik hatt1, nehir)" kapsayan şekillere dayalı çizimler yaptığı tespit edilmiştir. Ön testlerden elde edilen bu bulgular doğrultusunda öğrencilerin çoğunluğunun hidroelektrik santrali çizimlerinde sadece su ve baraj ünitelerine yer verdiği tespit edilmiştir. Son testlerden elde edilen bulgular doğrultusunda ise; öğrencilerin hidroelektrik 
santrali çizimlerinde su, baraj, türbin, jeneratör, elektrik hatt, nehir ünitelerinin hepsini kullandığı görülmektedir.

Öğrencilerin hidroelektrik santraline ilişkin ön testte verdikleri cevaplardan alıntılar aşağıdaki şekilde verilmiştir:

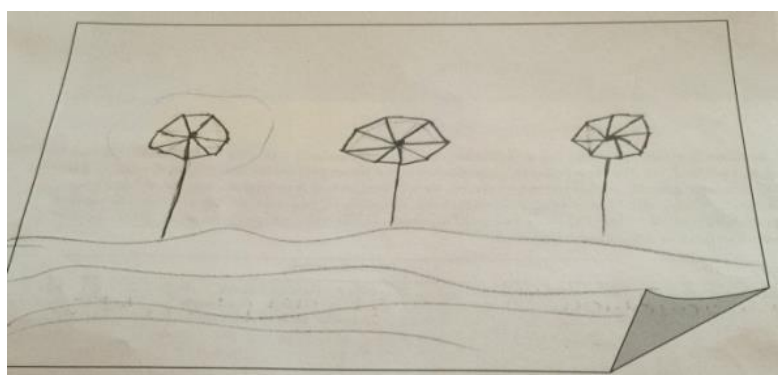

ö1 kodlu öğrencinin yanıtı

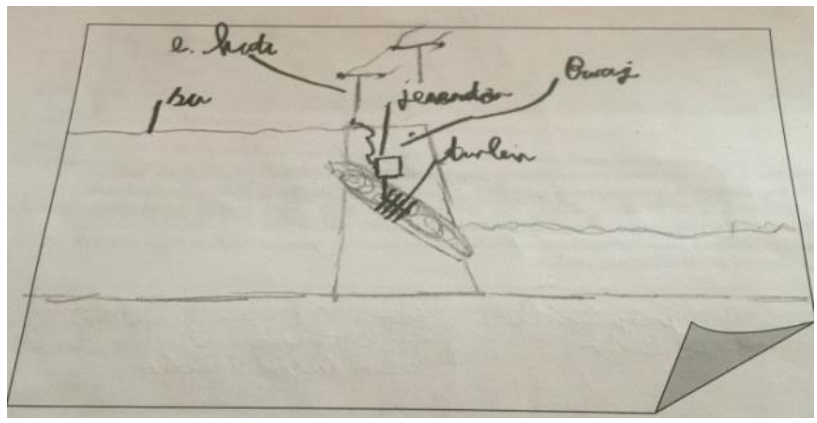

ö3 kodlu öğrencinin yanıtı

Öğrencilerin hidroelektrik santraline ilişkin son testte verdikleri cevaplardan alıntılar aşağıdaki şekilde verilmiştir:

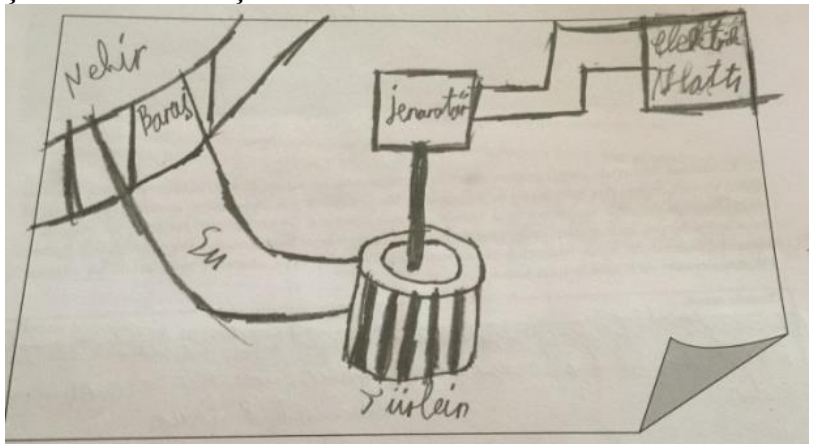

ö8 kodlu öğrencinin yanıtı

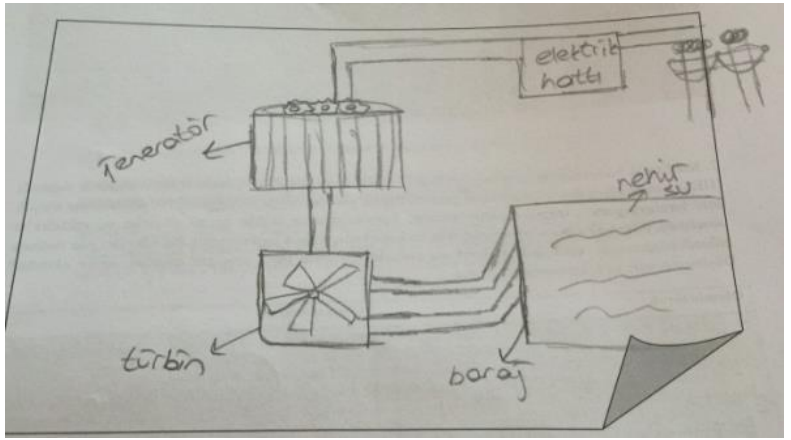

ö9 kodlu öğrencinin yanıtı 
HES'e yönelik olan kavramsal anlama testinde yer alan beşinci soru ile öğrencilerin hidroelektrik santralinde gerçekleșen enerji dönüşümüne ilişkin bilgileri belirlenmiștir. Cevapların analizi sonucunda elde edilen kod ve temalar ile bu kodların frekansı ve yüzde oranlarına Tablo 10' da yer verilmiştir.

Tablo 10

Hidroelektrik Santralinde Gerçekleşen Enerji Dönüşümüne İlişkin Öğrenci Cevapları

\begin{tabular}{|c|c|c|c|c|c|c|c|}
\hline & Şıılar & Ön test & Frekans & Yüzde & Son test & Frekans & Yüzde \\
\hline B. & $\begin{array}{l}\text { Hareket enerjisinin 1s1 } \\
\text { enerjisine ve daha sonra } \\
\text { elektrik enerjisine } \\
\text { dönüstürülmesi }\end{array}$ & $\begin{array}{r}\text { ö4,ö6,ö7,ö9,ö10, } \\
\text { o11,ö12,ö14,ö15, } \\
\text { ö16,ö17,ö18 }\end{array}$ & 12 & 57.14 & ö10 & 1 & 4.76 \\
\hline C. & $\begin{array}{l}\text { Is1 enerjisinin elektrik } \\
\text { enerjisine dönüştürülmesi }\end{array}$ & ö5,ö13 & 2 & 9.52 & & & \\
\hline D. & $\begin{array}{l}\text { Hareket enerjisinin elektrik } \\
\text { enerjisine dönüştürülmesi }\end{array}$ & ö1,ö3,ö19,ö20 & 4 & 19.05 & $\begin{array}{r}\text { ö1,ӧ2,ö3,ö4,ö5,ö6, } \\
\text { o7,ö8,ö9,ö11,ö12, } \\
\text { ö13,ö14,ö15,ö16, } \\
\text { ö17,ö18,ö19,ö20 }\end{array}$ & 19 & 90.48 \\
\hline E. & $\begin{array}{l}\text { Isı enerjisinin hareket } \\
\text { enerjisine ve daha sonra } \\
\text { elektrik enerjisine } \\
\text { dönüştürülmesi }\end{array}$ & ö2,ö8,ö21 & 3 & 14.28 & $\ddot{\mathrm{o}} 21$ & 1 & 4.76 \\
\hline & Toplam & Tüm öğrenciler & 21 & 100 & Tüm öğrenciler & 21 & 100 \\
\hline
\end{tabular}

Tablo 10'da hidroelektrik santralinde gerçekleşen enerji dönüşümüne ilişkin öğrencilerin kavramsal anlama ön testine verdiği cevaplar incelendiğinde; \%57.14'ünün "hareket enerjisinin 1s1 enerjisine ve daha sonra elektrik enerjisine dönüştürülmesi" olan B seçeneğini seçtiği görülmektedir. Aynı soruya ilişkin öğrencilerin kavramsal anlama son testine verdiği cevaplar incelendiğinde ise; \%90.48'inin "hareket enerjisinin elektrik enerjisine dönüştürülmesi” olan D seçeneğini seçtiği görülmektedir. Ön testlerden elde edilen bu bulgular doğrultusunda; öğrencilerin hidroelektrik santrallerinde üretilen elektrik enerjisinin hareket ve 1S1 enerjisine dayalı olduğunu vurguladığı görülmektedir. Son testlerden elde edilen bulgular doğrultusunda ise; öğrencilerin hidroelektrik santrallerinde üretilen elektrik enerjisinin hareket enerjisi sayesinde oluştuğunu belirttiği görülmektedir.

Öğrencilerin hidroelektrik santralinde gerçekleşen enerji dönüşümüne ve bu dönüşümün nedenine ilişkin ön testte verdikleri cevaplardan alıntılar aşağıdaki şekilde verilmiştir:

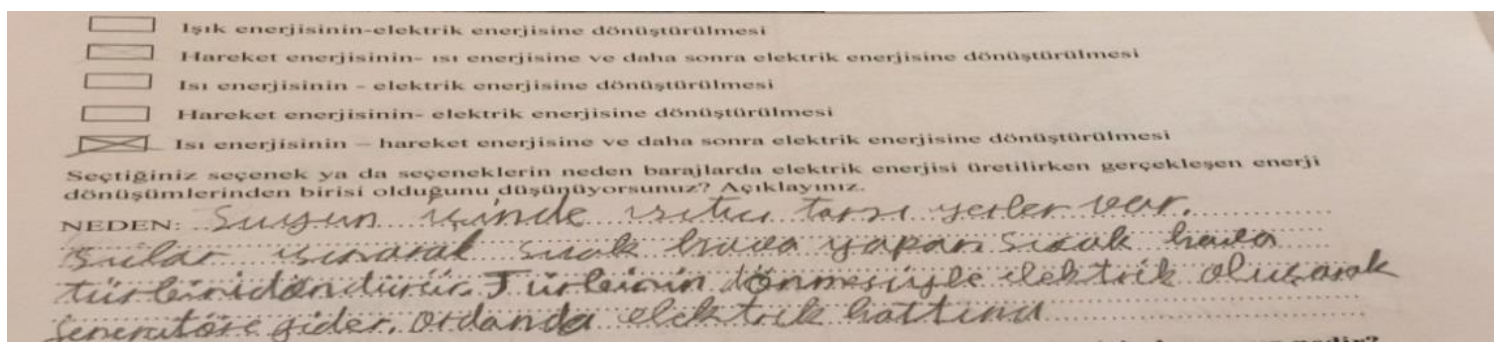

ö8 kodlu öğrencinin yanıtı

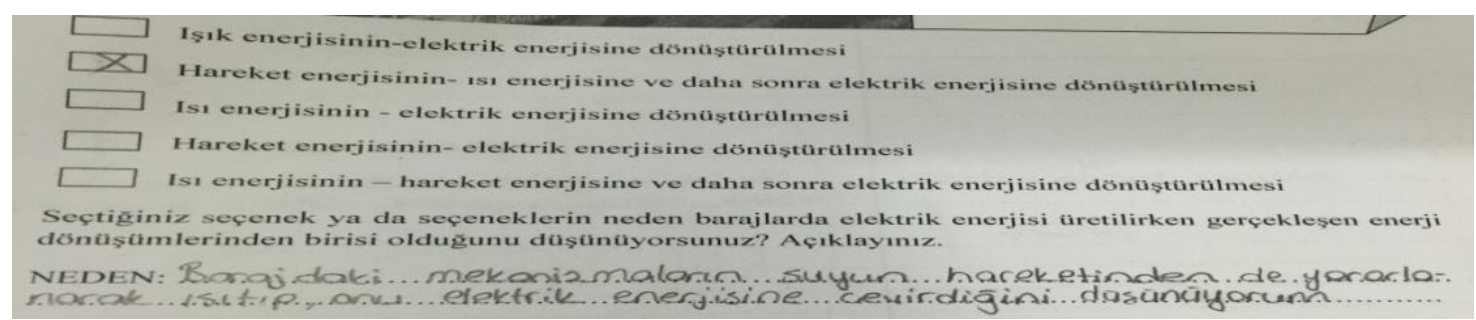

ö14 kodlu öğrencinin yanıtı 
Öğrencilerin hidroelektrik santralinde gerçekleşen enerji dönüşümüne ve bu dönüşümün nedenine ilişkin son testte verdikleri cevaplardan alıntılar aşağıdaki şekilde verilmiştir:

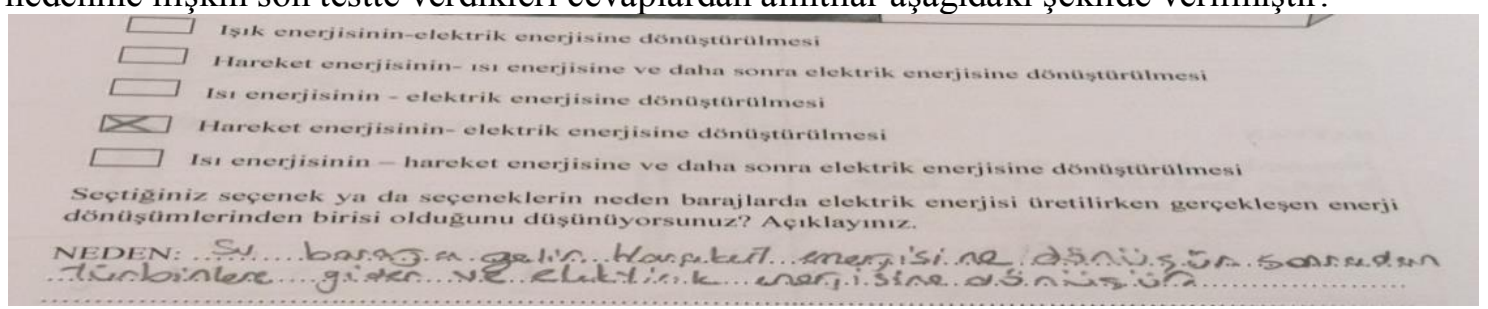

ö5 kodlu öğrencinin yanıtı

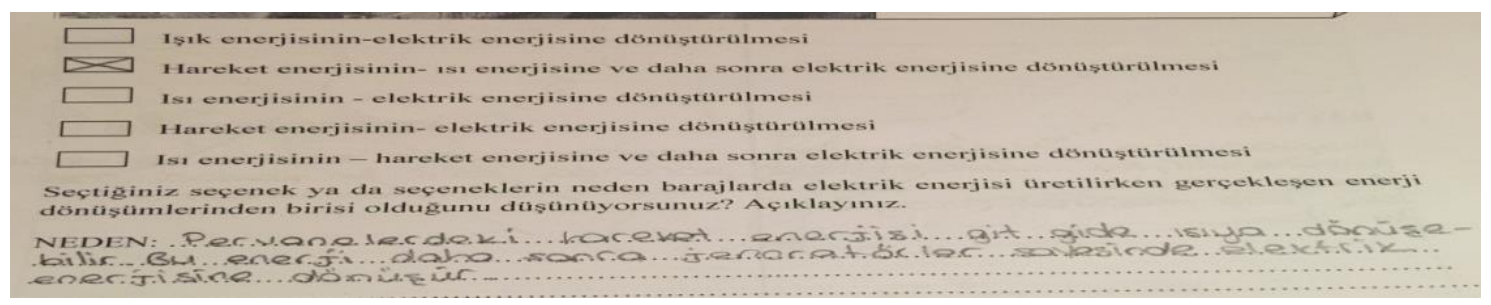

ö10 kodlu öğrencinin yanıtı

\section{Tartışma / Sonuç ve Öneriler}

Sosyobilimsel konulara dayalı okul dışı öğrenme ortamlarında yürütülen etkinliklerin çalışma grubunda yer alan öğrencilerin; kavramsal anlamalarına etkisinin incelendiği araştırmada; öğrencilerin HES'e, yönelik kavramsal anlama ön ile son test puan ortalamaları arasında son test lehine istatistiksel olarak anlamlı farklılıklar bulunmuştur [t20 $=-10.650, \mathrm{p}<0.05]$. Buna bağlı olarak sosyobilimsel konulara dayalı okul dışı öğrenme ortamlarında yürütülen etkinliklerin öğrencilerin kavramsal anlamalarını olumlu yönde etkilediği sonucuna ulaşılmıştır. Araştırma kapsamında HES'e yönelik elde edilen ön ve son nitel bulgularda bu istatistiki sonucu desteklemektedir.

Okul dışı öğrenme ortamları, bireye kendi öğrenme stiline ve hızına uygun öğrenmeler gerçekleştirmelerine imkan sunan öğrenme ortamlarıdır (Melber ve Abraham, 1999). Dolayısıyla öğrenme sürecini öğrenen kontrol etmektedir. Bu şekilde her birey geçmiş bilgi ve deneyimlerine bağlı olarak yeni edindiği deneyimleri kendine en uygun şekilde anlamlandırarak yapılandırabilir. Öğrencilerin sosyobilimsel konulara dayalı okul dışı öğrenme ortamlarında yürütülen etkinlikler sonrasında HES konusunda yer alan kavramlar hakkındaki ifadeleri kavramsal gelişimin gerçekleştiğinin göstergesidir. Çünkü öğrenciler HES konusuna yönelik son testlerde yer alan kavramları ön testlere göre daha yüksek oranda kendi cümleleri ile tanımlayabilmiş ve önceden bildiği kavramlar ile ilişkilendirerek açıklayabilmiştir. Demirelli (2003) bu şekilde kavramsal anlamaların gerçekleştiğini vurgulamıştır. Bu anlamda çeşitli sosyobilimsel konuların okul dışı öğrenme ortamlarında işlenmesiyle bu konulara dayalı öğrenmeler gerçekleşebilir. $\mathrm{Bu}$ bulgulara paralel şekilde literatürde okul dışı öğrenme ortamlarının öğrencilerin farkındalık ve bilgi düzeylerindeki değişimi (Bartley, Mayhew ve Finkelstein, 2009; Fisman, 2005; Pereira ve diğerleri, 2006; Randler ve diğerleri, 2012; Sanders, 2007), öğrenmelerini (Bätz, Wittler ve Wilde 2010; Tosun, 2012), kavramları anlama düzeylerindeki değişimi (Sağlamer Yazgan, 2013) olumlu yönde etkilediğini vurgulayan çalışmalar yer almaktadır. Ayrıca sosyobilimsel tartışma destekli öğretimin öğrencilerin bilgi düzeylerindeki değişimi (Şahintürk, 2014; Taşpınar, 2011) ve sosyobilimsel aktivitelerle verilen eğitimin kavram öğrenmelerini (Goloğlu, 2009) olumlu yönde etkilediğini inceleyen çalışmalara rastlanmıştır.

Bunun yanında araştırma kapsamında; hidroelektrik santralinde yürütülen uygulamalarda kazandırılması planlanan temel kavramlara ilişkin öğrencilerin görüşleri incelenmiştir. $\mathrm{Bu}$ doğrultuda hidroelektrik santrallerinin kurulup kurulmaması sosyobilimsel konusuna dayalı olarak hidroelektrik santralinde gerçekleştirilen uygulama kapsamında 
hidroelektrik santrali, hidroelektrik santralinde elektrik üretimi ve hidroelektrik santralinin en önemli ünitelerine ilişkin kavramların kazandırılması amaçlanmış ve öğrencilerin görüşleri belirlenmiştir. Bu doğrultuda bu kavramları içeren soruların yer aldığı hidroelektrik santraline yönelik kavramsal anlama ön ve son testlerinden elde edilen bulgular doğrultusunda; öğrencilerin çoğunluğunun hidroelektrik santrali tanımı yaparken kaynak olarak özellikle suyun çeşitli özelliklerinden, enerji dönüşümü ve makinalardan yararlanmasına dayalı açıklamalara yer vermiş olduğu tespit edilmiştir. Ayrıca bu öğrencilerin son test kodlarının sıklıklarının ön test kodlarınınkine göre bir artış gösterdiği bulunmuş̧tur. Ortaya çıkan bu durum; öğrencilerin hidroelektrik santrali tanımı yaparken sadece su ile ilgili açılkamalara yer vermediğinin bir göstergesidir. Dolayısıyla öğrencilerin özellikle uygulama sonrasında ayrıntılı bir hidroelektrik santrali tanımı yaptığı söylenebilir. Konuyla alakalı olarak; Kılıçaslan, Peker ve Gün (2011) ise ilköğretim öğrencileri ile yürüttükleri çalışmada; öğrencilerin hemen hemen yarısının hidroelektrik enerji kaynaklarını bilmediklerini belirlemiştir. Yangın, Geçit ve Delihasan (2012) öğretmen adayları ile gerçekleştirilen çalı̧̧mada, bu öğrencilerin hidroelektrik santraller konusu ile ilgili yeterli bilgi düzeyine sahip olmadıklarını ve bu konuyla alakalı bilgilendirilmeleri gerektiğini vurgulamıştır. Benzer şekilde Geçit ve Yangın (2012) bir başka çalışmalarında; öğretmen adaylarının aynı konu hakkında yeterli düzeyde bilişsel anlayışlarının olmadığını belirlenmiştir. Yapılan çalışmalar doğrultusunda literatürde gerek öğrencilerin gerek öğretmen adaylarının hidroelektrik santrali ile ilgili bilgi düzeylerinde eksikliklerin olduğu söylenebilir. $\mathrm{Bu}$ bağlamda bu araştırma kapsamında yürütülen uygulama ile; öğrencilerin kapsamlı hidroelektrik tanımı yaptığı göz önünde bulundurulursa, bu eksikliklerin giderilmesinde okul dışı öğrenme ortamlarının kullanımına yer verilmesi gerektiği ileri sürülebilir.

Hidroelektrik santralinde elektrik enerjisi üretimine ilişkin öğrencilerin cevapları incelendiğinde; uygulama öncesinde gerçekleştirilen ön testlerde öğrencilerin çoğunluğu hidroelektrik santralinde elektrik enerjisi üretiminin suyun yardımıyla gerçekleştiğini vurguladıkları, son testlerden ise; suyun yanında farklı madde ve makine yardımınında elektrik enerjisi üretiminde rol oynadığını belirttikleri görülmektedir. $\mathrm{Bu}$ durum öğrencilerin hidroelektrik santrali denildiğinde sadece su ile ilişkilendirmeye odaklı var olan algılarının değişim gösterdiğinin belirleyicisi olabilir. Bu durumun sebebi ise; öğrencilerin uygulamanın gerçekleştiği okul dışı öğrenme ortamında konuyla ilgili her türlü bilgiyi ayrıntılı olarak gözlemleyebilme fırsatı bulmaları ile açıklanabilir. Dolayısıyla öğrenciler hidroelektrik santralinde elektrik enerjisi üretilirken yalnızca suya ihtiyaç duyulmadığını kendileri tecrübe etmiş olurlar.

Bu bulguların yanında ön testler kapsamında öğrencilerin hidroelektrik santrali çizimleri incelendiğinde; çoğunluğunun çizimlerinde sadece su ve baraj ünitelerine yer verdiği tespit edilmiştir. Son testlerden elde edilen bulgular doğrultusunda ise; öğrencilerin hidroelektrik santrali çizimlerinde su, baraj, türbin, jeneratör, elektrik hatt1, nehir ünitelerinin hepsini kullandığı görülmüştür. Bu bulgular doğrultusunda uygulamadan önce öğrenciler; hidroelektrik santralinin su ve barajdan oluştuğunu düşünürken, yürütülen uygulama sonrasında ise; su ve baraj dışında hidroelektrik santralinin farklı üniteleri de kapsadığını vurgulamışlardır. Düşüncelerinin bu şekilde değişmesinin sebebi; öğrencilerin bu tür ortamlarda orijinal nesnelerle etkileşim içinde bulunarak somut deneyimler kazanmaları olabilir. Çünkü okul dışı öğrenme ortamları bireylere sınıf içerisinde sunulması güç olan ilk elden gözlem yapma ve deneyim kazanma firsatı sunmaktadır (Emmons, 1997; Rivkin, 2000). Bu sebepten öğrenciler görsel olarak yakından görerek tecrübe ettikleri nesneleri çizimlerine aktarmış olabilirler.

Son olarak; hidroelektrik santrallerinde üretilen elektrik enerjisine ilişkin öğrencilerin görüşleri incelendiğinde; uygulama öncesinde öğrencilerin çoğunluğu bu üretimin hareket enerjisinin 1sı enerjisine ve daha sonra elektrik enerjisine dönüştürülmesi ile gerçekleştiğini vurgulamıştır. Buna bağlı olarak hidroelektrik santralinde gerçekleşen enerji dönüşümü ile ilgili öğrencilerin bir takım yanılgılara ve hatalı bilgilere sahip olduğunu dile getirebiliriz. Oysaki son testlerden elde edilen bulgular doğrultusunda; öğrencilerin çoğunluğu bu dönüşümün; hareket enerjisinin elektrik enerjisine dönüştürülmesi ile gerçekleştiğini vurgulamıştır. Bu bulgular 
doğrultusunda okul dışı öğrenme ortamlarında yürütülen uygulamaların öğrencilerin yanılgılı ve hatalı bilgilerini düzeltmek anlamında önemli bir etkisi olduğu söylenebilir.

Sonuç olarak; sosyobilimsel konular, günlük yaşamın bir parçası olmasına rağmen birçok kişinin eksik bilgi ve yanılgıya sahip olması sebebiyle anlamakta ve yargıya varmakta zorlandığı konular olma özelliği göstermektedir. Özellikle geleceğin yetişkinleri olacak olan çocukların, hayatın her aşamasında yer alan bu tür tartışmalı ve sonuca varılmayan konular ile ileriki yaşamlarında bir gün bir şekilde karşı karşıya kalmaları söz konusu olabilir. Bu nedenle fen öğretim programının ön gördügü şekilde fen okuryazarı bireyler olarak sosyobilimsel konular hakkında nitelikli bilgi birikimine ve bilince sahip olmak ve buna bağlı olarak konuya ilişkin kararlar alabilecek düzeyde donanımlı olmak oldukça önemlidir. Okul dışı öğrenme ortamları ile; bireyler, bu tartışmalı ve çelişkili konuları, kavramların somutlaşmasına imkan tanıyan zengin öğrenme ortamlarında ve kendi kontrollerinde daha anlamlı ve kalıcı şekilde yapılandırabilirler. Bu sebeplere bağlı olarak; sosyobilimsel konuların ilgili okul dışı öğrenme ortamlarında işlenmesinin; öğrencilerin bu sosyobilimsel konuların kavramsal olarak öğrenilmesine olumlu yönde etkisi olmaktadır. Bu kapsamda okullarda formal eğitim kapsamında sosyobilimsel konular başta olmak ele alınan birçok konunun okul dışı öğrenme ortamları ile desteklenmesi gerektiği düşünülmektedir. Bu doğrultuda; okul dış1 öğrenme ortamlarının öğrencilerin çeşitli duyuşsal ve bilişsel becerileri üzerindeki uzun süreli etkisini tespit etmeye yönelik çeşitli çalışmalar yürütülebilir. Ayrıca eğitim ve öğretimin diğer unsurları olan veliler ve okul yöneticilerinin de bu konu hakkındaki görüşlerini belirlemeye yönelik çeşitli nitel araştırmalar yapılabilir.

\section{Kaynaklar}

Ary, D., Jacobs, L. C., Sorensen C. ve Razavieh, A. (2010). Introduction to research in education. (8th ed.). Belmont, CA: Wadsworth, Cengage Learning.

Bartley, J. E., Mayhew, L. M. ve Finkelstein, N. D. (November 2009). Promoting children's understanding and interest in science through informal science education. Physics Education Research Conference Proceedings.

Bätz, K., Wittler, S. ve Wilde, M. (2010). Differences between boys and girls in extracurricular learning settings. International Journal of Environmental \& Science Education, 5(1), 51-64.

Bell, R. L. ve Lederman, N. G. (2003). Understandings of the nature of science and decision making on science and technology based issues. Science \& Education, 87, 352-377.

Bilen, K. ve Özel, M. (2012). Üstün yetenekli öğrencilerin biyoteknolojiye yönelik bilgileri ve tutumlar1. NEF-EFMED, 6(2), 135-152.

Braund, M. ve Reiss, M. (2006). Towards a more authentic science curriculum: the contribution of out-of-school learning. International Journal of Science Education, 28(12), 13731388. doi.org/10.1080/09500690500498419

Büyüköztürk, Ş., Kılıç Çakmak, E., Akgün, Ö. E., Karadeniz, Ş. ve Demirel, F. (2008). Bilimsel araştırma yöntemleri. (2. Baskı). Ankara: PegemA Yayıncılık.

Charles, M. C. ve Mertler, C. A. (2002). Introduction to educational research. (4 ed.) Boston, MA; Allyn \& Bacon.

Cohen, J. (1988). Statistical power analysis for the behavioral sciences. Hillsdale, NJ: Lawrence Erlbaum Associates.

Dawson, V. (2007). An exploration of high school (12-17 year old) students' understandings of, and attitudes towards biotechnology processes. Research in Science Education, 37(1), 59-73 doi.org/10.1007/s11165-006-9016-7

Dawson, V. ve Venville, J. G. (2009). High school students' informal reasoning and argumentation about biotechnology: an indicator of scientific literacy. International Journal of Science Education, 31(11), 1421-1445. doi.org/10.1080/09500690801992870 
Demir, B. ve Düzleyen, E. (2012). İlköğretim 8. sınıf öğrencilerinin gdo bilgi düzeylerinin incelenmesi. X. Ulusal Fen Bilimleri ve Matematik Eğitimi Kongresi Özet Kitabı içinde, 27-30 Haziran 2012, Niğde: Niğde Üniversitesi Eğitim Fakültesi.

Demirelli, H. (2003). Yapılandırıcı öğrenme teorisine dayalı laboratuvar aktivitesi: elektrot kalibrasyonu ve gran metodu. G.Ü. Gazi Eğitim Fakültesi Dergisi, 23(2), 161-170.

Domaç, G. G. (2011). Biyoloji eğitiminde toplumbilimsel konuların ögrrenilmesinde argümantasyon tabanlı ögrenme sürecinin etkisi (Yayımlanmamış yüksek lisans tezi). Gazi Üniversitesi Eğitim Bilimleri Enstitüsü, Ankara.

Emmons, K. M. (1997). Perceptions of the environment while exploring the outdoors: a case study in belize. Environmental Education Research, 3(3), 327-344. doi.org/10.1080/1350462970030306

Fisman, L. (2005). The effects of local learning on environmental awareness in children: an emprirical investigation. The Journal of Enviromental Education, 36(3), 39-50. doi.org/10.3200/JOEE.36.3.39-50

Geçit, Y. ve Yangın, S. (2012). Öğretmen adaylarının hidroelektrik santralleri konusundaki bilişsel anlayışları. Pegem Ë̆itim ve Öğretim Dergisi, 2(4), 29-39.

Gerber, B. L., Marek, E. A., ve Cavallo, A. M. L. (2001). Development of an informal learning opportunities assay. International Journal of Science Education 23(6), 569-583. doi.org/10.1080/09500690116959

Goloğlu, S. (2009). Fen eğitiminde sosyo-bilimsel aktivitelerle karar verme becerilerinin geliştirilmesi: dengeli beslenme. (Yayınlanmamış yüksek lisans tezi). İstanbul: Marmara Üniversitesi Eğitim Bilimleri Enstitüsü.

Gündoğdu, F. (2011). Illkögretim fen ve teknoloji ders kitabı 8. N. Murat (Yay. haz.). Ankara: Altın Kitaplar Yayınevi.

Kılıçaslan, M., Aymen Peker, E. ve Gün, F. (2011,). Yenilenebilir enerji kaynaklarının çevreye olan katkısına ilişkin ilköğretim öğrenci görüşleri: Samsun İli Örneği. Samsun Sempozyumu, 2-6.

Kidman, G. (2010). What is an 'interesting curriculum' for biotechnology education? Students and teachers opposing views. Research in Science Education, 40(3), 353-373. doi.org/10.1007/s11165-009-9125-1

Klemmer, C. D., Waliczek, T. M. ve Zajicek, J. M. (2005). Growing minds: the effects of a school gardening program on the science achievement of elementary students. HortTechnology, 15(3), 448-452.

Kolstø, S. D. (2001). Scientific literacy for citizenship: tools for dealing with the science dimension of controversial socioscientific issues. Science Education, 85(3), 291- 310. doi.org/10.1002/sce.1011

MEB (2013a). Talim ve Terbiye Kurulu Başkanlı̆̆l, Illköğretim Kurumları Fen Bilimleri Dersi (3,4,5, 6, 7 ve 8. Sinıflar) Öğretim Programı. Ankara: MEB Yayınları.

MEB (2013b). İlköğretim fen ve teknoloji ders kitabı 7. G. Leblebicioğlu (Yay. haz.). (2. Baskı). Ankara: Millî Eğitim Bakanlığı Yayınları.

Melber, L. H. ve Abraham, L. M. (1999). Beyond the classroom: linking with informal education. Science Activities, 36(1), 3-4. doi.org/10.1080/00368129909601027

Melber, L. M. (2006). Informal science education: where we were..., where should we go? Science Activities, 43(2), 3-4. doi.org/10.3200/SATS.43.2.3-4

Merriam, S. B. (2013). Nitel araştırma: desen ve uygulama için bir rehber. (S. Turan Çev. Ed.). Ankara: Nobel Yayınc1lık.

Miles, M. B. ve Huberman, M. A. (1994). An expanded sourcebook qualitative data analysis. London: Sage Publication.

Ormanc1, Ü. ve Şaşmaz-Ören, F. (2010). Kavram karikatürleri, çizim, kelime ilişkilendirme testi ve kavram haritalarının ölçme-değerlendirme amaçlı kullanımına yönelik bir puanlama çalışması. Internetional Conference on New Horizons in Education Proceedings Book içinde. Famagusta, 23-25 Haziran 2010. 
Özdemir, O. (2005). İlköğretim 8. sınıf öğrencilerinin genetik ve biyoteknoloji konularina ilişkin kavram yanilgilari. On Dokuz Mayıs Üniversitesi Ĕgitim Fakültesi Dergisi, 20, 49-62.

Özden, M., Akgün, A., Çinici, A., Gülmez, H. ve Demirtaş F. (2013). 8. sınıf öğrencilerinin genetiği değiştirilmiş organizmalar (gdo) hakkındaki bilgi düzeyleri ve biyoteknolojiye yönelik tutumlarının incelenmesi. Adlyaman Üniversitesi Fen Bilimleri Dergisi, 3(5), 94-115.

Özden, M., Usak, M., Prokop, P., Türkoglu, A. ve Bahar, M. (2008). Student teachers' knowledge of and attitudes toward chemical hormone usage in biotechnology. African Journal of Biotechnology, 7(21), 3892-3899.

Pereira, R., Pinho, R., Lopes, L., Antunes, S.C., Abrantes, N. ve Gonçalves, F. (2006). Helping teachers to use urban natural areas for science teaching and environmental education. Fresenius Environmental Bulletin, 15(11), 1467-1473.

Ramey-Gassert, L. (1997). Learning science beyond the classroom. The Elementary School Journal, 4, 433-450.

Randler, C., Kummer, B. ve Wilhelm, C. (2012). Adolescent learning in the zoo: Embedding a non-formal learning environment to teach formal aspects of vertebrate biology. Journal of Science Education and Technology, 21(3), 384-391. doi.org/ 10.1007/s10956-0119331-2

Rivkin, M. S. (2000). Outdoor experiences for young children. Erişim adresi: http://ericae.net/edo/ed448013.htm

Sadler, T. (2004). Informal reasoning regarding ssi: a critical review of research. Journal of Research in Science Teaching, 41(5), 513-536. doi.org/ 10.1002/tea.20009

Sadler, T. D. ve Zeidler, D. L. (2004). The morality of socioscientific issues construal and resolution of genetic engineering dilemmas. Science Education, 88(1), 4-27. doi.org/ 10.1002/sce. 10101

Sağlamer Yazgan, B. (2013). Araştırmaya dayalı sınıf dışı laboratuar etkinliklerinin ögrencilerin araştırma-sorgulama becerilerine ve çevreye karşı tutumlarına etkisi (Yayımlanmamış doktora tezi). Marmara Üniversitesi Eğitim Bilimler Enstitüsü, İstanbul.

Salmi, H. (1993). Science centre education. motivation and learning in informal education. Unpublished Doctoral Dissertation. Helsinki University.

Sanders, D. L. (2007). Making public the private life of plants: the contribution of informal learning environments. International Journal of Science Education, 29(10), 1209-1228. doi.org/ 10.1080/09500690600951549

Şahin, Ç. ve Çepni, S. (2011). Yüzme-batma, kaldırma kuvveti ve basınç kavramları ile ilgili iki aşamalı kavramsal yapılardaki farklılaşmayı belirleme testi geliştirilmesi. Journal of Turkish Science Education (TUSED), 8(1), 79-110.

Şahin, S. (2013). Illköğretim fen ve teknoloji ders kitabı 7. A. Akar (Yay. haz.). Ankara: Sözcü Yayıncılik ve Pazarlama.

Şahintürk, G. M. (2014). Sosyo-bilimsel tartışma destekli fen etkinliklerinin 8. sinıf ögrencilerinin yenilenebilir enerji kaynakları ile ilgili farkındalıkları ve içerik bilgisi gelişimine etkisinin incelenmesi (Yayımlanmamış yüksek lisans tezi). Marmara Üniversitesi Eğitim Bilimleri Enstitüsü, İstanbul.

Taşpınar, P. (2011). Sosyobilimsel tartışma destekli sağlık ĕgitimi etkinliklerinin ilköğretim 5. sinıf öğrencilerinde să̆llk bilincinin ve içerik bilgisinin gelişimine etkisi (Yayımlanmamış yüksek lisans tezi). Marmara Üniversitesi Eğitim Bilimleri Enstitüsü, İstanbul.

Tosun, F. (2012). Illköğretim canlılar dünyasını gezelim tanıyalım ünitesinin anlaşılmasında gezi gözlem ve düz anlatım yöntemlerinin karşılaştırılması (Yayımlanmamış yüksek lisans tezi). Ondokuz Mayıs Üniversitesi Eğitim Bilimleri Enstitüsü, Samsun. 
Treagust, D. F. ve Chandrasegaran, A. L. (2007). The Taiwan national science concept learning study in an international perspective. International Journal of Science Education, 29(4), 391-403. doi.org/ 10.1080/09500690601072790

Usak, M., Erdogan, M., Prokop, P. ve Ozel, M. (2009). High school and university students' knowledge and attitudes regarding biotechnology. Biochemistry and Molecular Biology Education, 37(2), 123-130.

Ünver, E. (2014). Illkögretim fen ve teknoloji ders kitabı 8. Z. Arslan (Yay. haz.). Ankara: Dikey Yayıncilik.

Wellington, J. (1990). Formal and informal learning in science: the role of the interactive science centres. Physics Education, 25(5), 247-252.

Yangın, S., Geçit, Y. ve Delihasan, S. (2012). Öğretmen adaylarının hidroelektrik santralleri konusundaki görüşleri. Marmara Coğrafya Dergisi, 26, 124-146.

Yıldırım, A. ve Şimşek, H. (2011). Sosyal bilimlerde nitel araştırma yöntemleri. (8.Baskı). Ankara: Seçkin Yayıncılık.

\section{Extended Abstract \\ Introduction}

Due to the continuous progression of science and technology, the effects of socio-scientific issues are extremely seen in our daily life (Sadler \& Zeidler, 2004). Therefore, people of all ages in the society should be aware of these issues and they should be at the awareness level of giving an opinion on them (Bilen \& Özel, 2012). Considering that the new generation will be the prospective authorities of many segments of the society, the cruciality of their background knowledge and attitudes towards the socio-scientific issues becomes more notable. However, the lack of information and mistakes of the individuals on these contradictive issues and the concepts related to these issues which can be encountered any time or anywhere in the daily life are known.

Out-of-school learning environments which create different, improved and enriched learning environments enable the students to learn by doing and experiencing in various ways (Ramey-Gassert, 1997). Besides, complete and meaningful learning is ensured via providing opportunities for making observations and gaining experiences which are hard to be offered inside of a classroom (Emmons, 1997; Rivkin, 2000) and for the interaction with concepts and objects related to the science subjects (Ramey-Gassert, 1997). From this standpoint, many concepts and issues related to science education which are difficult to teach and emphasize via formal education can be easily given to the students. Therefore, it is thought that dealing with controversial and conflicting socio-scientific topics which are also hard to be conceptualized by the students within out-of-school learning environments offering various opportunities is significant. Thus, analyzing these social and contradictive issues within out-of-school learning environments can lead the students to examine them in their natural environment. Moreover, this study is believed to contribute to the literature regarding the existence of the studies on determining the conceptual understanding of the candidate teachers on socio-scientific topics in the literature. Accordingly, determining the effects of the activities carried out in out-of-school learning environments based on socio-scientific issues on the decision making of the $7^{\text {th }}$ grade students is the aim of this study.

\section{Method}

One group pretest-posttest experimental design was used for this study in which "the activities carried out in out-of-school learning environments based on socio-scientific issues" were the independent variable and "the conceptual understanding scores of the students" were the dependent variable. A five-question "Conceptual Understanding Test on Socio-Scientific Issues" which was developed by the researcher as pre-test and post-test for obtaining results of the dependent variable was also used. Qualitative data were obtained from this data collection tool which is generally used for quantitative data as well. 
There were twenty-one $7^{\text {th }}$ grade students enrolled in secondary school during the 20142015 academic year in the study group. Being a 7th grade student, being able to participate to the activities to be carried out in the out-of-school learning environments and having basic knowledge and interest on the socio-scientific issues and out-of-school learning environments were the predetermined criteria.

Within this study, which examines the effects of the activities carried out in out-ofschool learning environments based on socio-scientific issues, some out-of-school visits related to the socio-scientific issue were carried out. Therefore, the issue related to the foundation of Hydroelectric Power Plants (HPP) was discussed with the 21 students in the study group at ADASU Hydroelectric Plant on March 27, 2015 in accordance with the permissions taken from the Ministry of National Education, the school principal and the parents. Accordingly, pre- and post-tests for conceptual understanding on HPP were run before and after the visits and activities carried out in out-of-school learning environments. The total scores were calculated by quantification of the data obtained from Conceptual Understanding Test on Socio-Scientific Issues, via the scoring criteria developed by Şahin and Çepni (2011) and Ormancı and ŞaşmazÖren (2010).

\section{Result and Discussion}

In this study, significant differences on behalf of the post-test on the average scores of the preand post-tests on conceptual understanding of the students on HPP were found out. Thus, it was concluded that the activities carried out in out-of-school learning environments based on socioscientific issues positively affect the conceptual understandings of the students. The qualitative findings of the pre- and post-test results towards HPP also supported the above mentioned statistical finding.

The qualitative findings of the study revealed that the students used reference based explanations for the definition of the HPP before and after the practice. Additionally, the students especially made a detailed HPP definition after the practice. Besides, since the students had a chance of observing any kind of information on the topic extensively during the out-ofschool learning environment, they mentioned that HPPs do not only need water to produce electric energy in their report they gave after the visit which wasn't mentioned in the earlier one. Likewise, while the students thought that a HPP consists of water and a dam, after the practice they emphasized that a HPP has different units besides water and a dam. The reason that changed their ideas can be their experiences after the interaction to the real objects in these kinds of environments. As out-of-school learning environments enable students to observe by themselves and gain experience both of which are almost impossible to perform inside a classroom (Emmons, 1997; Rivkin, 2000). Finally, analysis of the opinions of the students on electric energy produced via HPPs presented that the students stated that the cycle of the production is transfer of the motion energy to the thermal energy and finally to the electric energy before the visit. Therefore, it can be implied that the students used to have some mistaken information on the transformation of energy in a HPP. However, the post-test revealed that majority of the students underlined that this transformation occurs when motion energy transforms to electric energy. In the light of these findings it can be stated that out-of-school learning environments have crucial role in correcting the mistakes and making up the lack of information of the students.

Since out-of-school learning environments enable the individuals to learn based on their own styles and speed (Melber \& Abraham, 1999), the learner can control the learning process. Therefore, each individual can structure the new experiences and knowledge by interpreting based on his/her background knowledge and past experiences. The statements of the students about the HPPs after the out-of-school learning environments based on socio-scientific issues can be considered as an indicator of conceptual development. Because the students were able to define the process with their own sentences and to explain the process by referring to the concepts they had already learned. 